Acta medico-historica Rigensia (2018) XI: 11-52

doi:10.25143/amhr.2018.XI.01

I. PĒTNIECISKIE RAKSTI

Jānis Stradiņ̌̌

\title{
Zinātne Latvijā: attīstības pamatmetu raksturojums (1775-2016)
}

\section{Anotācija}

Rakstā ieskicēti zinātnes attīstības pamatmeti Latvijā no Apgaismības laikmeta līdz mūsdienām, uzsverot arī Baltijas vācu zinātnieku lomu sākumposmā.

Vērienīgi pētījumi pēc 1862. gada izvērsās Rīgas Politehnikumā (RP, RPI), jo īpaši minams V. Ostvalda un P. Valdena ieguldījums ķīmijā. Pirmie latviešu tautības zinātnieki strādāja galvenokārt ārpus Latvijas. Tikai Latvijas Universitātes (LU) kā nacionālas universitātes dibināšana 1919. gadā radīja priekšnoteikumus to darbībai Latvijā.

Pēc 1945. gada zinātni Latvijā nācās integrēt vienotā PSRS zinātnes sistēmā. 20. gadsimta 60.-80. gados Latvijā attīstījās modernas zinātnes jomas, par pētniecības galveno centru kḷuva Zinātņu akadēmija ar pētniecības institūtu tīklu.

Latvijai atgūstot neatkarību, pētniecība atkal tika apvienota ar augstāko izglītību, konkurētspējīgākie zinātnes virzieni tika iekļauti Eiropas zinātnes telpā, attīstījās humanitārās zinātnes un letonika.

Darbā raksturoti ievērojamākie zinātnieki, zinātnes pašreizējā situācija un attīstību traucējošie faktori. ${ }^{1}$

Atslēgvārdi: zinātne, Rīgas Politehniskais institūts, Latvijas Universitāte, Latvijas Zinātņu akadēmija, pētnieciskie institūti, sasniegumi zinātnē, letonika.

1 Raksta pirmpublikāciju angḷu valodā sk.: Jānis Stradiṇš, "Science in Latvia," in Latvia and Latvians (Riga: Latvian Academy of Sciences, 2018), 1: 319-360. 
Zinātne ir internacionāla un daudzšķautņaina, taču tā veidojas konkrētās valstīs. Dažādu nāciju zinātnieki (arī nelielu tautu pārstāvji) dod savu pienesumu un piešķir kolorītu atsevišķām nozarēm. Īpaši raksturīgi tas bija senākos laikos, kad zinātne vēl nebija tik globalizēta. Šajā nozīmē drīkstam runāt par vietējās zinātnes attīstības vadlīnijām arī Latvijā un traktēt to kā vienotu vēsturisku procesu, mēǵinot izvērtēt, kādās jomās latviešu (t. i., Latvijā strādājošie) zinātnieki izpaudušies visspilgtāk, kur senāk darbojās un tagad strādā latviešu zinātnieks - dzimtenē vai ārpus tās, kā nākotnē varētu veidoties zinātne Latvijā.

Zinātnes attīstības vispārējā gaita Latvijā ir pētīta gan no pasaules zinātņu vēstures viedokḷa, gan kā būtiska Latvijas kultūrvēstures sastāvdaļa. $^{2}$

Angloamerikāņi tradicionāli mēdz šksirt eksaktās zinātnes un dabaszinātnes (science) no humanitārajām (humanities) zinātnēm, kamēr Vācijā, Ziemel̦eiropā un Austrumeiropā tiek uzsvērta to kopība (Wissenschaft, rayka, la science). Arī Latvijā un latviešu vidē tiek runāts par zinātni ${ }^{3}$ kopumā. ${ }^{4}$

Par Latvijas zinātni drīkst runāt laikposmā pēc Latvijas valstiskuma izveidošanās un Latvijas Augstskolas (Universitātes) dibināšanas 1919. gadā. Pirms tam zinātne šeit attīstījās triju Baltijas guberṇu ietvaros un galvenais augstākās izglītības un zinātnes centrs, kopējs tagadējai Latvijai un Igaunijai, bija 1802. gadā atjaunotā Tērbatas (Tartu) Universitāte. Tās loma ne tikai igauņu, bet arī latviešu nācijas izveidē un vietējās zinātnes

2 Jānis Stradiņš, Zinātnes un augstskolu sākotne Latvijā, 2. izd. (Rīga: Latvijas vēstures institūta apgāds, 2012). Grāmatā iekḷauts arī plašs historiogrāfisks apskats ar dažādu autoru vērēm; Ianis Stradyn, "Osnovnye etapy razvitiia estestvoznaniia v Latvii," in Iz istorii estestvoznaniia i tekhniki Pribaltiki (Riga: Zinatne, 1980), 4: 5-29; Jānis Stradiņš, Etīdes par Latvijas zinātņu pagāatni (Rīga: Zinātne, 1982); Jānis Stradiņš̆, "Zinātne un zinātnieks Latvijas vēsturē," Latvijas Zinātnnu Akadèmijas Vèstis, A dą̧a, 4/5/6 (2002), 91-101; Jānis Stradiņš, "Latviešu zinātnieki Latvijā un ārzemēs," Apvienotais Pasaules latviešu zinātnieku 3. kongress un Letonikas 4. kongress "Zinātne, sabiedrība un nacionālā identitāte". Rīga, 2011. gada 24.-27. oktobris. Plenārsēžu materiāli (Rīga: Latvijas Zinātņu akadēmija, 2012), 39-60.

${ }^{3}$ Latviešu valodā terminu zinātne ierosināja pedagogs un latviešu nacionālās atmodas dedzīgs atbalstītājs Atis Kronvalds 1873.-1874. gadā, taču tas iesakṇojās pamazām, galvenokārt tikai pēc Latvijas Republikas dibināšanas, jo ilgus laikus to aizstāja termins zin̄̄bas (знание, knowledge). Šie termini tradicionāli lietoti visu zinātnes nozaru kopības apzīmēšanai.

${ }^{4}$ Kārlis Mīlenbahs, Darbu izlase, 1. sēj. (Rīga: LU Latviešu valodas institūts, 2009), 201-206; Jānis Stradin̦š, Zinātnes un augstskolu sākotne Latvijā, 25-26. 
(akadēmiskās dzīves) tapšanā ir nepārvērtējama. Dominējošais elements Tērbatas Universitātē tās ziedu laikos, 19. gadsimtā, bija Baltijas vācu izcelsmes vai no Vācijas iecel̦ojušie zinātnieki. Šì universitāte bija savdabīgs, izcils zinātnes centrs Krievijas impērijā un viens no tās modernizācijas faktoriem. ${ }^{5}$

\section{Academia Petrina, zinātṇu biedrības, Rīgas Politehnikums}

Vēl pirms Tērbatas Universitātes dibināšanas Apgaismības laikmetā Jelgavā kopš 1775. gada darbojās Pētera akadēmija (Academia Petrina) akadēmiskā ǵimnāzija, kurai vārds dots par godu tās dibinātājam - pēdējam Kurzemes hercogam Pēterim Bīronam. Tajā kā profesori strādāja un starptautiski atzītus pētījumus veica Pēterburgas Zinātṇu akadēmijas locekḷi - mineralogs Johans Jākobs Ferbers, astronoms un matemātiķis Vilhelms Beitlers, vēlāk arī metrologs un astronoms Magnuss Georgs Paukers. ${ }^{6}$ Pieminams arī Rīgas zinātnieku pulciņš 18.-19. gs. mijā (fiziķis Georgs Frīdrihs Parrots un viņa draugs - pirmais latviešu izcelsmes dabaszinātnieks, farmaceits un mediķis Dāvids Hieronīms Grindelis, kuri veica Rīgā pirmos izgudrojumus medicīnā un farmācijāa). Grindelis 1803. gadā Rīgā dibināja pirmo Farmaceitiskās ķīmijas biedrību Krievijas impērijā.7

Deviņpadsmitajā gadsimtā ne Rīgā, ne Jelgavā nepastāvēja universitātes, toties rosīgi darbojās zinātniskās biedrības: Rīgas Praktizējošo ārstu biedrība (dib. 1822), Baltijas provinču vēstures un senatnes pētītāju biedrība (dib. 1834), Rīgas Dabaspētnieku biedrība (dib. 1845) u. c.

5 Roderich von Engelhardt, Die deutsche Universität Dorpat in ihrer geistesgeschichtlicher Bedeutung (Reval: Kluge, 1933); Karl Siilivask, ed. Tartu Ülikooli ajalugu, 1632-1982, 3 vols. (Tallinn: Valgus, 1982); Arnis Vīksna, Tērbatas Universitāte (Rīga: Zinātne, 1986); Gustavs Šaurums, Tērbatas universitāte, 1632-1932 (Rīga: Autora apgādībā, 1932); Jānis Stradiṇš, Zinātnes un augstskolu sākotne Latvijā, 437-470.

6 Jānis Stradiņš, Henrihs Strods, Jelgavas Pētera akadēmija: Latvijas pirmās augstskolas liktengaitas (Rīga: Zinātne, 1975); Jānis Stradiņš, Zinātnes un augstskolu sākotne Latvijā, 119-250; Jānis Klētnieks, Astronomija un geodēzija Latvijā lìdz 20. gadsimtam (R̄̄ga: LU Akadēmiskais apgāds, 2014).

7 Jānis Stradiṇš, red., No Grindeļa līdz mūsdienām: apceres par farmācijas tradīcijām un jaunu ārstniecības preparātu meklējumiem Latvijā (Rīga: Nordik, 1996); Jānis Stradiņš, Zinātnes un augstskolu sākotne Latvijā, 327-337. 
Jelgavā dibinātā Kurzemes Literatūras un mākslas biedrība (1815-1939) - pirmā reǵionālā zinātņu akadēmija Baltijas provincēs - tagadējās Latvijas Zinātṇu akadēmijas (LZA) Hartā tiek uzlūkota kā viena no LZA idejiskajām priekštecēm. ${ }^{8}$ Tās aktīvo biedru skaitā bija Jelgavas matemātikas profesors Magnuss Georgs Paukers, slavenais ķīmiķis un fiziķis Teodors Grothuss - pirmās elektrolīzes teorijas un fotoķīmijas pamatlicējs ( ̌̌īs biedrības sēdē pirmoreiz ziņots par fotoķīmijas pamatlikumu 1818. gadā), ${ }^{9}$ biologs Eduards Eihvalds, latviešu etnosa pētnieks un latviešu izglītošanas veicinātājs dzimtajā valodā Karls Vatsons u. c. Vēlāk par Kurzemes biedrības goda biedru kḷuva izcilākais latviešu etnosa pētnieks mācītājs Augusts Bīlenšteins (arī Pēterburgas ZA korespondētājloceklis), kura ieguldījums latviešu valodas un tās gramatikas, folkloras, etnogrāfijas un vēsturiskās ǵeogrāfijas izpētē ir nepārvērtējams. Bīlenšteina atziņas izmantotas jaundibināmās Latvijas Republikas ǵeogrāfisko robežu nospraušanā 1918.-1920. gadā (pēc etniskā principa). ${ }^{10}$

8 Wilfried Schlau, "Die Kurländische Gesellschaft für Literatur und Kunst und das Kurländische Provinzialmuseum zu Mitau," in Baltische Hefte, Bd. 14 (HannoverDöhren, 1968), 5-107; Jānis Stradiňš, Latvijas Zinātņu akadēmijai 50 gadi: divās daļās. 1. daļa, Latvijas Zinātņu akadēmija: izcelsme, vēsture, pārvērtības (Rīga: Zinātne, 1998), 711; Jānis Stradiṇš, Zinātnes un augstskolu sākotne Latvijā, 363-436; Jahresverhandlungen der Kurländischen Gesellschaft für Literatur und Kunst, 2 Bd. (Mitau: J. F. Steffenhagen und Sohn, 1819-1822); Jānis Stradiňš, "Kurzemes Literatūras un mākslas biedrība (1815-1939) - zinātṇu akadēmijas aizsākums Latvijā," Latvijas Zinātņu Akadēmijas Vēstis, A dal̦a, 1/2 (2006): 4-18; Janis Stradin̄š, "Courland Society of Letters and Arts - the first point of reference for the Academies of Sciences in the Baltic," in Academies of Sciences for Research and Innovation: Past and Future: proceedings of the $14^{\text {th }}$ Baltic Conference on Intellectual Cooperation, ed. I. Šteinbuka (Riga: Latvian Academy of Sciences, 2016), 100-107.

9 Theodor Grothuss, Abhandlungen über Elektrizität und Licht (Leipzig: W. Engelmann, 1906). (Ostwald's Klassiker der exacten Wissenschaften, nr. 152); Ianis Stradyn, Teodor Grotgus, 1785-1822 (Moskva: Nauka, 1966); Jānis Stradiṇš, Zinātnes un augstskolu sākotne Latvijā, 377-382.

10 Ināra Korsaka, sast., Starptautiskās zinātniskās konferences "Dr. Augusts Bīlenšteins par latviě̌u kultūras pamatvērtībām - arī Eiropā” referātu krājums (Rīga: Latvijas Akadēmiskā bibliotēka, 2007); Jānis Stradiṇš, "Augusta Bīlenšteina devumu un likteni latvieša acīm XX gadsimta nogalē pārlūkojot," no Kāda laimīga dzīve: Dobeles mācītāja Dr. A. Bīlenšteina autobiogrāfija, Bīlenšteins A. (Rīga: Rīgas Multimediju centrs, 1995), 372-387; Jānis Stradiņš, Zinātnes un augstskolu sākotne Latvijā, 471-524; August Bielenstein, Lettische Grammatik (Mitau: F. Lucas Buchhandlung, 1863); August Bielenstein, Die lettische Sprache nach ihren Lauten und Formen erklärend und vergleichend, Th. 1, Die Laute. Die Wortbildung (Berlin: F. Dümmler, 1863); Ibid., Th. 2: Die Wortbeugung (Berlin: F. Dümmler, 1864); Sarma Kl̦aviņa, 
Veikuma nozīmības ziṇā Augusts Bīlenšteins salīdzināms ar Kurzemes hercogistē mītošo 18. gs. latviešu apgaismotāju - literātu, teologu, valodnieku Gothardu Frīdrihu Stenderu, kurš iedibināja latviešu valodniecību un laicīgo literatūru, neparasti vērien̄̄gi popularizēja tālaika zinātnes atziņas latviešu lasītājiem, pārsvarā dzimtcilvēkiem ("Augstas gudrības grāmata no pasaules un dabas”, 1774. g., 1776. g. un īpaši 1796. g. papildinātais izdevums; šādai "zemnieku enciklopēdijai" nebija analogu tā laika Eiropā). ${ }^{11}$ G. F. Stenderu, K. Vatsonu un A. Bīlenšteinu - luterāṇu lauku mācītājus var uzlūkot par letonistikas tālīniem aizsācējiem laikmetā, kad lietuviešu un latviešu valodu senatnīgā un būtiskā loma indoeiropiešu valodu izcelsmes un radniecības izprašanai pasaules mērogā tika parādīta līdz ar salīdzināmās valodniecības tapšanu un baltu valodu grupas jēdziena izveidošanos.

Nākamais posms pētniecības attīstībā sākas ar Latvijas teritorijā pirmās augstskolas - Rīgas Politehnikuma (RP) - dibināšanu 1862. gadā, kas vēlāk transformējās par Rīgas Politehnisko institūtu (RPI, 1896) un 1919. gadā kḷuva par bāzi Latvijas Universitātei. ${ }^{12}$

Kā praktiski un tehnoloǵiski orientēta augstskola RPI būtiski sekmēja Rīgas un Baltijas guberṇu modernizāciju un industrializāciju pirms Pirmā pasaules kara. Līdzās Tērbatas Universitātei tā veidojās par otru pētniecības centru toreizējā Baltijā, kur veikti fundamentāli pētījumi ar nenoliedzamu atzinību pasaules zinātnē, īpaši ķīmijā un inženierzinātnēs. ${ }^{13}$

Latviešu valodas pētnieki: no klaušu laikiem līdz savai valstij: darbu izlase (Rīga: RaKa, 2008), 25-51. A. Bīlenšteina pamatgrāmatas par latviešu valodu, gramatiku, latviešu cilšu robežām 2011. gadā tika pārdrukātas "Nabi Press" apgādā Indijā un joprojām ir nozīmīgi letonistikas avoti.

11 Zigrīda Frīde, Latvis. Gothards Frīdrihs Stenders (Rīga: Zinātne, 2003); Gotfrīds Frīdrihs Stenders, Augstas gudrības grāmata no pasaules un dabas (Jelgava, Aizpute: J. F. Hinc, 1774), 2. izd. (1776), 3. izd. (1796); Gothards Fridrihs Stenders, Augstas gudrības grāmata no pasaules un dabas: 1796. gada izdevuma teksts ar ievadrakstiem un komentāriem (Rīga: Liesma, 1988); Jānis Stradin̄š, Zinātnes un augstskolu sākotne Latvijā, 471-524.

12 1958. gadā Rīgas Politehniskais institūts tika atjaunots un kopš 1990. gada tiek saukts par Rīgas Tehnisko universitāti.

13 Juris Briedis et al., Augstākās tehniskās izglītības vēsture Latvijā, 1. daḷa: Rīgas Politehnikums. Rīgas Politehniskais institūts 1862-1919 (Rīga: RTU, 2002); Jānis Stradiņš un Ilgars Grosvalds, "Rīgas Politehniskais institūts (1862-1919) - zinātnes un Latvijas progresa virzītājs," no Rīgas Tehniskās universitātes vēstures lappuses, Acta Historiae Scientiarum Baltica (9), red. Andris Krēsliņš et al. (Rīga: RTU, 1992), 9-51. 
Nozīmīgi ir pētîjumi fizikālajā un organiskajā ķīmijā, ko veica Rīgā dzimušais Vilhelms Ostvalds (RP profesors 1881-1887) un Vidzemes latviešu zemnieka dēls, RP absolvents Pauls Valdens (docētājs un profesors Rīgā 1889-1919). Par Rīgā aizsāktajiem ķīmiskā līdzsvara un katalīzes pētījumiem V. Ostvalds vienīgais no Rīgā strādājušajiem zinātniekiem 1909. gadā ir saņēmis Nobela prēmiju. V. Ostvalda Rīgas posma veikumu dēl ķīmijas vēsturē 1887. gadu atzīst par fizikālās ķīmijas tapšanas gadu pasaulē. ${ }^{14}$ Ostvalda Rīgas laboratorijā vēlāk kā vieszinātnieks slavenais zviedru zinātnieks Svante Arrēniuss izstrādāja elektrolītiskās disociācijas (brīvo jonu) teorijas un ķīmisko reakciju ātruma teorijas (kinētikas) zinātniskos pamatus. ${ }^{15}$

Savukārt V. Ostvalda skolnieks Pauls Valdens Rīgā atklāja optiskās inversijas parādību (Valdena inversija), pamatoja naftas izcelšanās biogēno teoriju un deva fundamentālas atziņas š̌k̄īumu teorijā. Viņu atzīst par neūdens šķ̄idumu elektroķīmijas pamatlicēju. Līdz pat mūsdienām Valdenu uzskata par izcilāko latviešu izcelsmes zinātnieku, kura sasniegumi joprojām tiek minēti enciklopēdijās, citēti mācību grāmatās un analizēti nozaru literatūrā; kopš 1913. gada viņš septiņas reizes nominēts Nobela prēmijai ķ̄īmijā, kuru tomēr nav saņēmis. ${ }^{16}$ Ostvaldam un Valdenam Rīgā uzstādītas piemiņas zīmes, kopš 1998. gada Rīgā regulāri tiek rīkoti P. Valdena simpoziji organiskajā ķīmijā.

14 Paul Walden, Wilhelm Ostwald (Leipzig: W. Engelmann, 1904); Wilhelm Ostwald, Lebenslinien - eine Selbstbiographie. Nach der Ausgabe von 1926/27 überarb. und komment. von K. Hansel, Abhandlungen der Sächsischen Akademie der Wissenschaften zu Leipzig. Naturwissenschafliche Klasse (Leipzig: Sächsische Akademie Wissenschaften zu Leipzig, 2003, 61); Ianis Stradyn, "Rizhskii period deiatelnosti Vilgelma Ostvalda i stanovlenie klassicheskoi fizicheskoi khimii," Izvestiia Akademii Nauk Latviiskoi SSR 7 (1979): 33-44.

15 Elisabeth Crawford, Arrhenius. From Ionic Theory to the Greenhouse Effect (Canton: Science History Publications, 1996), 320.

16 Ianis Stradyn i Iurii Solovev, Pavel Ivanovich (Paul) Valden, 1863-1957 (Moskva: Nauka, 1988); Paul Walden, Wege und Herbergen: mein Leben (Wiesbaden: Steiner, 1974); Ilze Andersone, sast., Akadēmiķis Pauls Valdens = Akademik P. I. Valden: biobibliogrāfiskais rādītājs (R̄̄ga: Zinātne, 1983); Jānis Stradiñš, Trešā atmoda: raksti un runas 1988.-1990. gadā Latvijā un par Latviju (Rīga: Zinātne, 1992), 316-331; Jānis Stradiņš, "Izcilais zinātnieks Pauls Valdens un viṇa 150 gadu jubileja - UNESCO pasaules gadskārtu sarakstā," no Zinātnes un kultūras mijiedarbība Latvijā un pasaulē: Jāņa Stradiña gada grāmata, (Rīga: LU Akadēmiskais apgāds, 2015), 146-156. 2011. gadā Amerikas Ķ̄īmijas biedrība piešķ̄irusi RTU savu memoriālo plaketi par 1896. gada Valdena publikācijas rekordilgo citējamību. 
No citiem "vecajā” RPI (1862-1919) strādājošiem zinātniekiem minami fiziķis Augusts Tēplers (atklājis šlīru metodi - teplerogrāfiju, ar ko pirmoreiz vizuāli novērota skaņa), matemātiķis Pīrss Bols (nekustīgā punkta teorēma, kvaziperiodiskās funkcijas) elektromašīnbūves speciālists Engelbrehts Arnolds, fotogrammetrijas celmlauzis Alvils Buholcs, cementa tehnoloǵiju izstrādātājs Maksimiliāns Glāzenaps, kvartārǵeoloǵijas speciālists Karls Bruno Doss, vairāki izcili inženierzinātnieki, arī viens no astronautikas un raķešu būves pamatlicējiem Frīdrihs Canders, kurš pētījumus šajā jomā aizsācis vēl studenta gados RPI (1905-1914). Vilhelms Ostvalds, Augusts Tēplers, Svante Arrēniuss, Nikolajs Žukovskis, Sergejs Vinogradskis un jau mūsdienās sakarā ar RPI dibināšanas 150. gadskārtu (2012) post mortem arī Pauls Valdens, Frīdrihs Canders, Mihails DoḷivoDobrovoḷskis, Ignācijs Moscickis un vairāki citi godināti, piešksirot tiem RPI Goda biedra nosaukumu. ${ }^{17}$

Vairākums pieminēto zinātnieku ir vācu izcelsmes (vai nu vācbaltieši, vai no ārvalstīm iecelıjušie). Pēdējā laikā Latvija tiecas šos zinātniekus iekļaut savā nacionālajā kultūras mantojumā. Baltijas vācu loma vietējās zinātnes un akadēmisko tradīciju tapšanā, vēstures avotu edīcijā grūti pārvērtējama. UNESCO starptautiski atzīmējamo jubileju sarakstā tika ierakstīts G. F. Stendera 300. dzimšanas gads (2014), Kurzemes Literatūras un mākslas biedrības dibināšanas 200. gadskārta (2015), kā arī P. Valdena 150. dzimšanas gads (2013). Tiesa, jāatzīst, ka Baltijas vācu politiskā, administratīvā un intelektuālā elite līdz pat Latvijas neatkarības pasludināšanai kavēja latviešu izvirz̄̄̌šanos akadēmiskajā dzīvē. Pirmie latviešu vai latviskas izcelsmes zinātnieki (kā D. H. Grindelis, P. Valdens) izvirzījās, integrēdamies vācu vidē vai neuzsverot savu tautību.

\section{Pirmie latviešu zinātnieki - dzimtenē un ārpus tās}

Pirmie akadēmiski izglītotie cilvēki, kas identificējās kā latvieši un piedalījās topošās latviešu nācijas sabiedriskajā dzīvē, 19. gs. vidū nāca no jaunlatviešu aprindām. Krišjānis Valdemārs, Krišjānis Barons (pēc izglītības astronoms), Fricis Brīvzemnieks, Jānis Krodznieks (Krīgers) u. c. darbojās kā amatierzinātnieki, zināšanu un izglītības popularizētāji,

17 Juris Briedis et al., Augstākās tehniskās izglītības vēsture Latvijā, 5. daḷa: Rīgas Tehniskā universitāte (Rīga: RTU, 2016). 
folkloras kārtotāji, vietējās vēstures iztirzātāji no latviešu viedokḷa. Šajā vidē tapa pirmie profesionālie zinātnieki. Šie cilvēki pakāpeniski pārṇēma no baltvācu mācītājiem latviešu valodniecību (Kārlis Mīlenbahs, Jānis Endzelīns), ļoti bagātās latviešu folkloras vākšanu un kārtošanu (K. Barons, F. Brīvzemnieks), zinību popularizēšanu latviešu tautā (K. Valdemārs, K. Barons), sludinot, ka latviešu nācijas pārstāvji vislabāk spēj izkopt savas tautas valodu un tās vērtības (Juris Alunāns, Atis Kronvalds). ${ }^{18}$ Nemirstīgs ir Krišjāṇa Barona devums - savāktas, akadēmiski sakārtotas un izdotas (ar Pēterburgas ZA atbalstu) monumentālās "Latvju Dainas" (1894-1915). Sešu sējumu izdevumā iekḷautas 217996 tradicionālās latviešu tautasdziesmas - četrrindes, ko daudzu gadu gaitā bija savācis K. Barons, F. Brīvzemnieks u. c. ${ }^{19}$

Deviņpadsmitā gadsimta beigās un divdesmitā gadsimta sākumā latvieši zinātnē ienāca visbiežāk Iekškrievijas centros (Pēterburgā, Maskavā, arī Ukrainas universitātēs) ${ }^{20}$, tādēl nosacīti varam runāt par latviešu pirmo intelektuālo trimdu. K. Valdemārs strādāja Pēterburgā un Maskavā (veica arī tautsaimnieciska rakstura pētījumus). F. Brīvzemnieks un K. Barons dainu izpēti un izdošanu sāka Krievijā.

Arī latviešu veterinārārsts un mikrobiologs Kristaps Helmanis maleinu (preparātu zirgu l̦auno ienāšu diagnosticēšanai) atklāja Pēterburgā (1891), ${ }^{21}$ ķīmiķ̧is Jūlijs Auškāps turpat pirmoreiz spektroskopiski noteica krāsvielas uz tekstilšksiedru virsmas (1910), fiziologs un bioķīmiķis Roberts Krimbergs karnitīnu - mūsdienu bioķīmijai ļoti nozīmīgu vielu - izdalīja Maskavā (1905), turpat fiziķis Vilis Altbergs, Pjotra Ļebedeva skolnieks, pirmoreiz izmērīja skaņas spiedienu (1902). Tautsaimnieks Kārlis Balodis savus pētījumus tautsaimniecībā un statistikā veica Vācijā un Krievijā. Pat dižākais latviešu valodnieks Jānis Endzelīns līdz 1920. gadam strādāja kā

18 Jānis Bērziņš, red. Latvija 19. gadsimtā: vēstures apceres (Rīga: Latvijas vēstures institūta apgāds, 2000).

19 Krišjānis Barons un Henrijs Visendorfs, sast. Latvju Dainas = Латылискія народныя песни = Chansons populaires lataviennes, 6 sēj. (Jelgava; Pēterburga, 1894-1915).

20 Fricis Mīlenbahs, Latvieši un latvietes Krievijas augstskolās (Jelgava: H. Alunāna drukātava, 1908).

21 Egons Dārziņš, Zemmers, Kalniņš, Helmanis. Dzīve un darbi, 2. izd. (Rīga: Zinātne, 1993); Maleina atklāšana uzskatāma par pirmo ievērību guvušo latviešu veikumu mikrobiologijas zinātnē. K. Helmanis uzturēja zinātniskos kontaktus ar L. Pastēru, 1886. gadā dibināja pirmo Pastēra institūtu Krievijā (Pēterburgā). 
profesors Harkovas universitātē, kur tapa viņa monumentālā "Latviešu gramatika" (grāmata iespiesta Heidelbergā 1922). ${ }^{22}$ Arī sinologs Pēteris Šmits, arheologs Francis Balodis, mediķis Mārtiņš Zīle un jauno mediķu plejāde no Pēterburgas Kara medicīnas akadēmijas (Pēteris Sniķers, Jēkabs Alksnis, Pauls Stradinsš u. c.) 19. gs. beigās un 20. gs. sākumā profesionālo karjeru aizsāka Krievijā vai Ukrainā.

Protams, jauno latviešu inteliğentu un potenciālo zinātnieku šūpulis vēl lielākā mērā bija arī Tērbatas Universitāte un Rīgas Latviešu biedrība (RLB), kuras Zinību komisiju (RLB ZK, 1869) var uzskatīt par pirmo neoficiālo latviešu zinību akadēmiju. ${ }^{23}$ Latviešu amatierzinātnieki starptautiskā auditorijā pirmoreiz uzstājās 1896. gadā X Krievijas Arheologijas kongresā Rīgā (Luda Bērziṇa, Jāṇa Krodznieka referāti, pārskati par latviešu etnogrāfisko izstādi, kas tika sarīkota kongresa norises laikā). RLB kopš 1876. gada izdeva periodisku zinātnisku rakstu krājumu latviešu valodā, izstrādāja latviešu jauno ortogrāfiju uz latīṇu raksta bāzes (1908). ${ }^{24}$ K. Mīlenbahs ar RLB ZK atbalstu Rīgā sāka veidot savu ievērojamo etimoloǵisko skaidrojošo "Latviešu valodas vārdnīcu”, kuru pabeidza un jau neatkarīgās Latvijas laikā izdeva viņa līdzgaitnieks J. Endzelīns. ${ }^{25}$ Zinību komisijā latviešu problēmas pētīja amatierzinātnieki ārpus augstskolām un oficiālām pētniecības institūcijām (vēlāk, jau 1932. gadā, minētā komisija P. Šmita un J. Endzelīna vadībā tika pārveidota par privātu zinātṇu akadēmiju - Academia Scientiarum Latviensis SRL, kas pastāvēja līdz 1940. gadam). ${ }^{26}$ Arī šīs institūcijas Latvijas Zinātņu akadēmija atz̄̄st par savām priekštecēm.

22 Janis Endzelin, Lettische Grammatik (Riga: A. Gulbis, 1922).

23 Jānis Stradin̦š, Latvijas Zinātņu akadēmija: izcelsme, vēsture, pārvērtības, 76-94.

24 Sarma Kl̦avin̦a, Latviešu valodas pētnieki: no klaušu laikiem līdz savai valstij, 116-165; Jansone Ilga, Pareizrakstības reformas simtgade. Letonikas otrais kongress: Plenārsēžu materiāli (Rīga: Latvijas Zinātṇu akadēmija, 2008), 36-56; Jānis Stradiṇš, "Par ortogrāfiju un tautas kultūras identitāti," Latvijas Vēstnesis, 6. augusts, 2008, 35.

25 Kārlis Mīlenbahs, Latviešu valodas vārdnīca, 4 sēj., red. Jānis Endzelīns (Rīga: Kultūras fonds, 1923-1932).

26 Ludvigs Adamovičs, "Latviešu zinātnes šūpulis Rīgas Latviešu biedrībā: Zinību komisija un Zinātņu komiteja," no Rīgas Latviešu biedrības Zinātņu komitejas rakstu krājums, 23. krāj., A. Humanitāri raksti (Rīga: R. L. B. Derīgu grāmatu nodaḷa, 1940), 14-23; Jānis Stradiņš un Dzintra Cēbere, "Rīgas Latviešu biedrības Zinātņu komitejas darbība: sasniegtais un nepaveiktais. 1932-1940," Latvijas Vēstures Institūta Žurnāls, 3 (1993): 88-111. 
A. Kronvalds un J. Alunāns jau 1856.-1874. gadā sāka veidot zinātnisku terminolog̣iju latviešu valodā, ko pilnveidoja RLB ZK izdotās "Konversācijas vārdnīcas" (1903-1921) un vēlāk monumentālās "Latviešu konversācijas vārdnīcas" (1927-1940) sastādītāji. ${ }^{27}$ Pirmā pasaules kara bēgḷ gaitās dzima nodoms organizēt latviešu universitāti un arī latviešu zinību akadēmiju (Maskavā un Tartu, 1916-1917). Ideju par vienotu latviešu universitāti, kas ietvertu sevī arī zinātņu akadēmiju, 1916. gadā izvirzīja Maskavas Universitātes maǵistrants Pauls Dāle, kas vēlāk kḷuva par LU organizatoru un filozofijas profesoru. ${ }^{28}$

\section{Pētniecība Latvijas Universitātē un citās pētniecības institūcijās Latvijas Republikā 1919.-1940. gadā}

Latvijai iegūstot valstisku neatkarību 1918. gadā un izveidojot Latvijas augstskolu (Universitāti), par galveno pētniecības centru Latvijā kḷuva Latvijas Universitāte (LU). Latvijas Republikas Saeimas 1923. gada 16. martā pieņemtajā Latvijas Universitātes Satversmē noteikts, ka tā ir "augstākā zinātnes un izglītības iestāde valstī. Tās uzdevumos ietilpst: veicināt zinātnisko pētīšanu un zinātnes izplatī̌sanu tautā un gatavot Latvijas vajadzībām darbiniekus ar augstāko izglītību". ${ }^{29}$ LU sasniegumi pētniecībā 20 gados apkopoti LU jubilejas grāmatās, ${ }^{30}$ krājumā "Zinātne tēvzemei divdesmit gados, 1918-1938"31 un daudzos jaunāka laika izdevumos. ${ }^{32}$ Lai gan mūsdienās Latvijā pastāv vairākas universitātes (6),

27 Arveds Švābe, Aleksandrs Būmanis un Kārlis Dišlers, red. Latviešu konversācijas vārdnīca, 21 sēj. (Rīga: A. Gulbis, 1927-1940).

28 Pauls Dāle, “Latviešu augstskola,” Dzimtenes Atbalss (Maskava), 26. marts, 1916, 1.; 30. marts, 1916, 1-2; 2. aprīlis, 1916, 1-2; Pauls Dāle, Vēsturisks pārskats par Latvijas Augstskolas nodibināšanu un viņas darbību pirmā (1919./20.) mācības gadā (Rīga: Latvijas Augstskola, 1921).

29 “Latvijas Universitātes Satversme," Valdības Vēstnesis, 28. marts, 1923, 1-3.

30 Latvijas Universitāte, 1919-1929 (Rīga: Latvijas Universitāte, 1929); Latvijas Universitāte divdesmit gados, 1919-1939, 2 sēj. (Rīga: Latvijas Universitāte, 1939).

31 Ludvigs Adamovičs, red., Zinātne tēvzemei divdesmit gados, 1918-1938 (Rīga: Latvijas Universitāte, 1938).

32 Tālivaldis Vilciņš, "Zinātne Latvijas Republikā (1918-1940)," Latvijas Zinātņu Akadēmijas Vēstis, 6 (1991): 97-112; Jānis Stradiṇš, "Latvijas Universitātes veidošanās, tās devums Latvijai un pasaules zinātnei," Latvijas Vēstures Institūta Žurnāls, 2 (1995): 108-131; Alberts Varslavāns, red., Latvijas Universitāte, 75 (Rīga: Latvijas Universitāte, 1994); Henrihs Strods, red., Latvijas Valsts Universitātes vēsture, 1940-1990 (Rīga: Latvijas Universitātes žurnāla “Latvijas Vēsture” fonds, 1999). 
augstskolas un daudzi pētnieciski institūti, taču LU ar savu pētniecības centru struktūru joprojām ir zinātnisko pētījumu galvenā veicēja, tās starptautiskie reitingi starp vietējām universitātēm ir augstākie, tā ir pietuvojusies zinātnes universitātes statusam. ${ }^{33}$

Latvijas Universitāte lielā mērā veidojusies uz RPI bāzes, saņemot mantojumā ēkas, daudzu fakultāšu profesūru, inventāru un arī tradīcijas. Atšksirībā no RPI Latvijas Universitāte bija pilna profila universitāte, turklāt pirmā nacionālā universitāte Latvijā, kurā mācības notika latviešu valodā un kura veidojās atbilstoši nelielas valsts (nevis Krievijas impērijas) vajadzībām.

Daudzas nozares kā akadēmiskas disciplīnas Latvijā aizsākās līdz ar universitātes dibināšanu, proti, humanitārās zinātnes - filozofija, filoloǵija, vēstures zinātne, literatūrzinātne, arī medicīna un veterinārmedicīna, reliǵijas zinātne, dal̦ēji - fizika, matemātika, dabaszinātnes, tiesību zinātnes un tautsaimniecības zinātnes (kuras pirms tam nelielā mērā bija jau pārstāvētas RPI). Citām nozarēm - ksīmijai, mehānikai, inženierzinātnēm, arī lauksaimniecības zinātnei - bija jau agrāk RPI radītas tradīcijas un zinātniskas skolas. Ar LU dibināšanu reāli mainījās docētāju (un arī pētnieku) personālijas, zinātnē ienāca daudzi pirms tam Krievijā vai Rietumos strādājuši latvieši no citām augstskolām. Bija jāveido jauna pētniecības bāze, jāpilnveido zinātniskā terminolog̣ija latviešu valodā.

Humanitārās zinātnes uzskatīja par nacionālās un valstiskās identitātes uzturēšanas nozīmīgāko faktoru. Atšksirībā no iepriekšējiem laikmetiem, kad latviešu valodu lielā mērā pētīja cittautu pētnieki, bet vietējo vēsturi interpretēja galvenokārt no Baltijas vācu viedokḷa, pētniecībā iesaistījās

33 2016. gadā pasaules labāko universitāšu reitingā Latvijas Universitāte jau trešo gadu iekḷuvusi 650-700+ grupā (salīizinājumam - Tartu Universitāte ir 347. vietā, Viḷņas Universitāte 481.-490. vietā, Tallinas Tehnoloǵijas institūts 600.-650. vietā). Citas Latvijas universitātes šajā reitingā nav iekḷautas, taču arī to situācija nav pel̦ama. 2014. gada beigās publicēts šīs pašas organizācijas Quacquarelli Symonds (QS) pētījums, kas veikts Eiropas komisijas uzdevumā un aptver reǵionu, kas nosaukts par jauno Eiropu un Centrālo Āziju (Emerging Europe and Central Asia) un aptver visu Austrumeiropu, Turciju un bijušajā PSRS teritorijā funkcionējošās universitātes. Simts labāko universitāšu skaitā ierindojusies LU (41. vieta), RTU (grupā no 60. līdz 70. vietai), kā arī Rīgas Stradiṇa universitāte (RSU, bijušais Rīgas Medicīnas institūts, kas izdalīts no LVU 1950. gadā) ieskaitīta grupā 90.-100. vietā, turklāt RSU patlaban ir procentuāli lielākais ārvalstu studentu skaits. Sk.: Mārcis Auziṇš, "Nacionālās universitātes loma mazā valstī," no Zinātnes un kultūras mijiedarbība Latvijā un pasaulē: Jāņa Stradiņa gada grāmata, 29-43. 
latviešu zinātnieki, kuri prioritāri akcentēja pamattautības - latviešu īpatnības, to devumu Latvijas vietējā kultūrā un vēsturē. Atzīts latviešu valodniecības līderis bija profesors Jānis Endzelīns, kurš jau 20. gados izdeva savus lieldarbus un izvērsa pētījumus par baltu valodām kopumā (arī par senprūšu valodu), kḷūdams par pasaules mēroga autoritāti baltologijā un Eiropā ievērojamāko LU profesoru. ${ }^{34}$

Pēteris Šmits veica pētījumus valodniecībā, folkloristikā un mitologijāa (par latviešu pasakām un ticējumiem), turpināja pētīt eksotiskās Tālo Austrumu valodas (mandžūru, tungusu u. c.). Nozīmīga figūra bija filozofijas profesors Teodors Celms, kura sniegtā Huserla mācības analīze izpelnījās starptautisku ievērību kā šīs filozofijas perfekts izklāsts (1928. gadā vācu valodā, pēc tam 1931. gadā spāņu valodā, vēlāk tā izdota arī ASV). ${ }^{35}$

Ievērojamākais latviešu tautsaimniecības teorētiķis bija kādreizējais Berlīnes Universitātes profesors Kārlis Balodis, kura savulaik l̦oti populārā, ar pseidonīmu Atlanticus publicētā grāmata "Der Zukunftsstaat” izdota Berlīnē 1927. gadā četros izdevumos. Viņš izveidoja t. s. valsts kapitālisma teoriju un iniciēja vēlāk populārās Vasilija L Leontjeva starpnozaru bilances metodes input-output koncepcijas būtiskus elementus. Vēriena un jaunu atziṇu ğenerēšanas ziņā viņš bija starptautiska mēroga cilvēks, taču viṇa pārstāvētie uzskati mūsdienu ekonomikas zinātnē nav kḷuvuši par dominējošiem. ${ }^{36}$

Nozīmīgi pêtījumi veikti arī dabaszinātnēs, īpaši ķīmijā. Starptautisku ievērību izpelnījās Alfrēds Vītols ar saviem pētījumiem hidraulikā un kā Ķeguma HES būves, Dancigas brīvpilsētas ostas izbūves un vairāku Latīņamerikas (Peru) problēmu zinātniskais konsultants, tāpat arī geodēzijas profesors Alvils Buholcs ar novatoriskiem risinājumiem fotogrammetrijā. ${ }^{37}$ Vilhelma Ostvalda, Paula Valdena, Mečislava Centneršvēra,

34 Jānis Endzelīns, Darbu izlase, 4 sēj. (Rīga: Zinātne, 1971-1982); Kārlis Egle un Jānis Paeglis, sast., Akadēmiķis Jānis Endzelīns: bibliogrāfija. (Rīga: Latvijas PSR Zinātņu akadēmijas izdevniecība, 1958); Valentīna Skujiņa, red., Jānis Endzelīns atmiņās, pārdomās, vēstulēs (Rīga: Latvijas Universitātes Latviešu valodas institūts, 1999).

35 Maija Kūle, Līva Muižniece un Uldis Vēgners, Teodors Celms: fenomenologiskie meklējumi (Rīga: LU FSI, 2009).

36 Nikolajs Balabkins, Manfrēds Šneps, Kad Latvija būs labklājības valsts. Tautsaimnieks Kārlis Balodis (Rīga: Zinātne, 1993); Kārlis Balodis, Ievads tautsaimniecībā un ekonomiskā politika (Ogre: I. Prūsis, 2013).

37 Jānis Klētnieks, Ģeodēzijas izglītība un zinātne Latvijā, 1862-1990 (Rīga: RTU Izdevniecība, 2012). Latvijas Zinātņu akadēmijas Goda doktors J. Klētnieks ir A. Buholca idejiskais skolnieks, kurš veiksmīgi attīstījis viņa idejas Ėǵiptes piramīdu pētījumos. 
Valdemāra Fišera, Oskara Luca iedibinātās tradīcijas ķ̄īmijā turpināja Bruno Jirgensons pētījumos (likumība par aminoskābju konfigurāciju, 1932), Edvīns Iegrīve un Gustavs Vanags jaunu organisku krāsu reaǵentu meklējumos neorganisko un organisko savienojumu mikroanalīzei, izstrādājot l̦oti jutīgas, pasaules praksē plaši ieviestas metodes. Mārtiņš Eduards Straumanis radīja jaunas pieejas korozijas pētniecībā, kuru dēl tā laika speciālisti runāja par Baltijas korozionistu skolu. Mārtiņš Eduards Straumanis sadarbībā ar Alfrēdu Ieviṇu 1935.-1937. gadā izstrādāja jaunu precīzijas metodi kristālu elementāršūnu parametru noteikšanai (asimetriskā metode), ko savulaik plaši lietoja rentgena laboratorijās. ${ }^{38}$ Medicīnā Mārtiņš Zīle centās izstrādāt jaunu sintētisku pieeju slimībai un pacientam, izveidojot starptautisku mediķu zinātnisku kustību tās īstenošanai un organizējot starptautiskus kongresus, arī Rīgā (1930, 1932, 1934, 1936). Viṇa grāmata "Über das Weltbild des Arztes und den Sinn der Krankheit" (1934) rosināja diskusijas. Zviedru profesors Gastons Bakmanis un vina skolnieks Jēkabs Prīmanis pētīja latviešu un lībiešu antropoloǵiju, Pauls Stradiņš deva jaunas atziņas par perifēro nervu ārstēšanu un obliterējošā endarterīta (spontānās gangrēnas) izcelsmi, lika pamatus organizētai pretvēža cīņai (onkoloǵijai) Latvijā, sāka veidot Medicīnas vēstures muzeju, kas kḷuva par vienu no plašākajām šāda veida institūcijām pasaulē. ${ }^{39}$

No LU strādājošiem profesoriem cittautiešiem minami šveiciešu farmakologs Cēzars Amslers, norvēǵu zoologs Embriks Strands, austriešu tiesu mediķis Ferdinands Neireiters, ǵeologs Ernests Krauss, patologs Romāns Adelheims (visi minētie bija Vācu dabaspētnieku akadēmijas Leopoldina locekḷi), izcilie vēsturnieki Roberts Vipers un Leon̄̄ds Arbuzovs, mineralogs Boriss Popovs, ekonomists Vladimirs Kosinskis, slāvu literatūras speciālisti Julians Kžižanovskis un Staņislavs Kolbuševskis, mākslas vēsturnieks Boriss Vipers, tiesībzinātnieki Vasilijs Sinaiskis un Augusts Lēbers, mežsaimniecības ekonomists Eižens Ostvalds, kuriem netika liegts lasīt lekcijas svešvalodās. Īpaši jāizcel jaunajā LU izaugušie zinātnieki, kuri ap 1940. gadu jau dominēja visās nozarēs un bija arī starptautiski atzīti dažādu zinātņu jomu lietpratēji, kā, piemēram, M. E. Straumanis.

38 Ludvigs Adamovičs, red., Zinātne tēvzemei divdesmit gados, 1918-1938 (Rīga: Latvijas Universitāte, 1938), 143-174.

39 Arnis Vīksna, Pa profesora Paula Stradiņa mūža takām (Rīga: Paula Stradiņa Medicīnas vēstures muzejs, 2018), 96. 
Divdesmit gados LU bija izveidojusies par pietiekami ievērotu Eiropas universitāti un reg̣ionālu pētniecības centru. To sekmēja arī autoritārā Valsts prezidenta Kārḷa Ulmaņa zinātnes politika, īpaši dinamiskā un patriotiski noskaņotā LU rektora Jūlija Auškāpa ierosmes (Zinātniskās pētniecības fonds, sabatiskie atvaļinājumi pētnieciskajam darbam, modernu pētniecisko iekārtu iegāde). ${ }^{40}$ Agrārajai Latvijai būtiski bija pētījumi lauksaimniecības zinātnēs un mežzinātnēs, 1939. gadā Jelgavā tika dibināta īpaša Lauksaimniecības akadēmija (tagadējā Latvijas Lauksaimniecības universitāte - LLU), ko organizēja uz LU Lauksaimniecības fakultātes bāzes.

Ārpus LU darbojās Latvijas vēstures institūts, ko 1936. gadā dibināja Latvijas Republikas Ministru prezidents Kārlis Ulmanis, lai pētītu Latvijas vēsturi "patiesības un nacionālisma" garā, to vadīja profesori Augusts Tentelis, Arveds Švābe un Francis Balodis. Institūts aizsāka noz̄̄mīgu darbu vēstures avotu apzināšanā un izdošanā, pretēji baltvācu izveidotajai "Landesgeschichte" rosināja pētīt latviešu etnisko vēsturi un tautas vēsturi. Objektīva vēstures pētniecība te gan savijās ar senatnes idealizēšanu, pārspīlētām emocijām, K. Ulmaņa slavināšanu, taču pozitīvais devums bija pārsvarā, arī avotu edīcijas. Šis institūts turpināja pastāvēt dažādu režīmu laikos ar kardināli mainītām ideoloǵiskām nostādnēm un nosaukumiem. Latvijas vēstures institūts tagad darbojas kā LU zinātniska institūcija ar atzītiem pētîjumiem Latvijas vēsturē un arheoloǵijā, pašreiz tam uzticēta arī totalitāro režīmu dokumentu (VDK arhīvu) un kolaborācijas vēstures izpēte. ${ }^{41}$ 1936. gada 14. janvāra likumā par Latvijas vēstures institūtu ir uzsvērts, ka, "dibinoties Latvijas Zinātñu akadēmijai, Vēstures institūts ieies tajā kā viņas pirmā sastāvdaḷa". ${ }^{42}$

No citām pētnieciskām institūcijām ārpus universitātes minami Zemes bagātību pētǐšanas institūts (dib. 1936), Latviešu folkloras krātuve (1924)

40 Jūlijs Auškāps, Zinātnei un tēvijai, 3. papild. izd. (Rīga: Artava, 1993), 80-81; Jānis Stradiņš, "Prezidenta Kārḷa Ulmaņa zinātnes politika," Zinātnes Vēstnesis, septembris (1993): 2-3.

41 Jānis Graudonis, "Latvijas vēstures institūts Latvijas Republikas laikā. 1936.-1940. gads," Latvijas Vēstures Institūta Žurnāls, 4 (1995): 9-18; Indulis Ronis, "Latvijas vēstures institūts laikmeta kontekstā,” Latvijas Vēstures Institūta Žurnāls, 4 (1995): 19-36; Guntis Zemītis, "Nacionālā identitāte un valstiskums Latvijas vēsturē (Sakarā ar Latvijas vēstures institūta 75 gadiem)," Zinātnes Vēstnesis, 9. maijs, 2011, 3; 23. maijs, 2011, 3; Jānis Stradiņš, "Latvijas PSR ZA Vēstures institūta pārtapšana par Latvijas vēstures institūtu: 1988.-1993. gads," Latvijas Vēstures Institūta Žurnāls, 3 (2011): 9-33.

42 “Likums par Latvijas vēstures institūtu," Vald̄̄bas Vēstnesis, 17. janvāris, 1936, 1. 
un Latviešu valodas krātuve (1935), bija iecerēta arī Dabaszinātņu institūta dibināšana. Šksiet, uz to bāzes kombinācijā ar RLB Zinātṇu komiteju (Academia Scientiarum Latviensis SRL), kas pēc K. Ulmaņa norādījuma tika reorganizēta, bija iecerēts dibināt Zinātņu akadēmiju, par kuras nepieciešamību diskutēja visā Latvijas Republikas pastāvēšanas laikā (Kārlis Kasparsons, Pauls Dāle, Kārlis Balodis, Jānis Endzelīns, Pēteris Zālīte, Jānis Rainis, Kārlis Ulmanis), taču atšķirībā no Igaunijas līdz 1940. gadam ZA Latvijā oficiāli dibināta netika. ${ }^{43}$

Ar Latvijas zinātnieku līdzdalību pirmskara neatkarīgajā Latvijā veidojās vairākas inovatīvas ražošanas nozares (piemēram, serumu, vakcīnu, insulīna ražošana Augusta Kirhenšteina un Egona Dārziņa vadībā), radiouztvērēju, telefonu, pat oriǵinālu lidmašīnu izlaide valsts rūpnīcā VEF. Par Latvijas veiksmes stāstu tiek atzīta pasaulē mazākā fotoaparāta VEF Minox pilnveidošana un izlaide šajā rūpnīcā 1938.-1942. gadā pēc Rīgā dzimušāā izgudrotāja autodidakta Valtera Capa ierosmes, ko VEF konstruktori izstrādāja līdz lietojamai konstrukcijai. ${ }^{44}$

Trīsdesmito gadu beigās Latvija, kaut embrionālā veidā, sāka nostāties uz inovatīvas, zinātnē balstītas industrijas cel̦a, kāds raksturīgs, piemēram, Somijai. Diemžēl šo virzību aprāva Otrais pasaules karš un Latvijas aneksija.

\section{Latvijas zinātne laikmetu griežos, otra trimda un Latvijas PSR ZA dibināšana}

1939.-1945. gads iezīmēja dramatisku pavērsienu arī Latvijas zinātnē - Baltijas vācu zinātnieku izcel̦ošanas, staļinisko represiju un holokausta, latviešu inteliǵgences masveida emigrēšanas dēl uz Rietumiem (1944-1945) Latvija zaudēja 60-65 \% akadēmisko mācībspēku. Daļa emigrējušo zinātnieku (eksakto zinātņu un dabaszinātņu pārstāvji, arī neliels skaits mediķu un humanitāri sociālo zinātṇu pārstāvju) varēja turpināt un pat izvērst akadēmisku karjeru ārzemēs kā profesori Rietumeiropas, Amerikas, Austrālijas universitātēs (Leons Āboliṇš, Oto Mellis, Heinrihs

43 Jānis Stradiṇš, Dzintra Cēbere, "Latvijas Zinātṇu akadēmijas veidošanās: zinātniskie un sabiedriski politiskie aspekti," Latvijas Vēstures Institūta Žurnāls, 3 (2006): 90-114.

44 Arvīds Deǵis, "Valters Caps - Minox fotoaparāta tēvs," no Latvijas légendas (Rīga: Jumava, 2012), 2: 52-63. 
Skuja, Staņislavs Vasil̨evskis, Alfreds Tauriņš, Aleksis Dreimanis, Leonīds Slaucītājs, Sergejs Slaucītājs, Jēkabs Prīmanis, Eduards Dunsdorfs, Haralds Biezais, Mārtiņš Eduards Straumanis u. c.). ${ }^{45}$

Ļoti daudzi latviešu jaunieši no trimdinieku ǵimenēm izvēlējās par dzīves aicinājumu akadēmisku darbu jaunajās mītnes zemēs (otra-intelektuālā trimda), 20. gs. 60.-70. gados latviešus Amerikā dažkārt pat dēvēja par profesoru tautu. Fiziķis Konstantīns Počs piedalījās raķešu aizsardzības sistēmas AWACS izstrādē, savukārt Juris Upatnieks (arī ASV) bija iekḷauts Nobela prēmijas laureātu kandidātu - finālistu "īsajā sarakstā” (1971) kā viens no hologrāfijas atklājējiem. ${ }^{46}$

Ne mazāku atzinību pelnījuši tie latviešu zinātnieki, kuri 1944.1945. gadā palika dzimtenē ar nedrošām un neskaidrām nākotnes izredzēm. Tieši viņi lielā mērā l̦āva saglabāt Latvijā pētniecību, pamazām izaudzināt jaunu zinātnieku paaudzi, nel̦aujot, ka zinātni Latvijā pilnībā pārṇem iebraucēji no citām PSRS republikām, kuru vidū bija arī labi zinātnieki, tostarp daudzi Krievijas latvieši (Lidija Liepiṇa, Jānis Peive, Aleksandrs Šmits, Jānis Zutis, Jānis Lūsis u. c.). ${ }^{47}$

Vērtējot komunistiskā režīma attieksmi pret zinātni Padomju Latvijā, jāievēro, ka zinātne attīstījās lielvalsts - PSRS ietvaros, Maskava bija ieinteresēta izvērst zinātni ne tikai savos lielajos centros, bet arī savienotajās republikās, tostarp anektētajā Baltijā, kurai pēc 1953. gada bija iecerēta tāda kā PSRS "rietumnieciskās vitrīnas" loma. ${ }^{48}$ Pēc Otrā pasaules kara būtiski palielinājās zinātnes - īpaši tehnisko un eksakto zinātṇu - prestižs

45 Jānis Stradiņš, "Latvian science in exile and its reintegration with science in Latvia," Proceedings of the Estonian Academy of Sciences. Humanities and Social Sciences, 44, no. 2 (1995): 129-137.

46 Andris Ozols, "Hologrāfijas celmlauzis Juris Upatnieks," Akadēmiskā Dzīve, 45 (2008): 101-108.

47 Jānis Stradiņš, “Totalitāro okupācijas režīmu represijas pret Latvijas zinātni un akadēmiskajām aprindām (1940-1945)," no Totalitārie okupācijas režīmi Latvijā 1940.1964. gadā: Latvijas Vēsturnieku komisijas 2003. gada pētījumi, sast. Dzintars Ērglis, Latvijas Vēsturnieku komisijas raksti (Rīga: Latvijas vēstures institūta apgāds, 2004), 13: $130-164$.

48 Jānis Stradinšs, "Staļina režīma attieksme pret Latvijas zinātniekiem un akadēmiskajām aprindām," no Okupētā Latvija, 1940-1990: Latvijas Vēsturnieku komisijas 2005. gada pêtījumi = Occupied Latvia, 1940-1990: research of the Commission of the Historians of Latvia 2005, Latvijas Vēsturnieku komisijas raksti (Rīga: Latvijas vēstures institūta apgāds, 2007), 19: 408-448. 
un nozīmība gan saistībā ar militāro tehnoloǵiju izstrādi (kodolieroči un kosmiskās raķetes), gan ar impērijas varenības nodrošināšanu aukstā kara apstākḷos. Lai gan tika gādāts par zinātniski tehniska profila lietišksajiem institūtiem (tādi pēc 1956. gada sāka veidoties arī Latvijā), tomēr zinātni traktēja pietiekami plaši, attīstot teorētiskās zinātnes, medicīnu, arī humanitārās zinātnes, tiesa, stingri ideoloǵizētos un politizētos ietvaros (kas sākotnēji skāra pat biolog̣iju).

Vairākumam dzimtenē palikušo latviešu zinātnieku Josifa Staļina laikā bija jāpieredz pazemojošas represijas, daudzi zaudēja darbu, veselību un iespējas netraucēti veikt pētījumus. Bija iecerēta tālejoša Baltijas sovjetizācija, arī zinātnes jomā. Pētniecību šķ̄ira no augstākās izglītības, koncentrējot to jaundibinātās Latvijas PSR Zinātṇu akadēmijas institūtos vai Latvijā dislocētos vissavienības institūtos lietišķo pētījumu attīstībai un industrializācijas forsēšanai. No "buržuāziskajiem nacionālistiem" attīrītajai Latvijas Valsts universitātei bija jākḷūst par "ideoloǵisku kadru kalvi”" vai arī par profilētu speciālistu sagatavošanas vietu, lai gan, protams, arī tur sašaurinātā veidā turpinājās pētniecība. ${ }^{49}$

Latvijas PSR Zinātñu akadēmija tika dibināta ar LPSR Tautas komisāru (Ministru) padomes 1946. gada 7. februāra lēmumu. Pirmie Padomju Latvijas valdības ieceltie ZA īstenie locekḷi bija valodnieks Jānis Endzelīns, ǵeogrāfs Matvejs Kadeks, mežķīmiķis Arvīds Kalniņš, mikrobiologs un veterinārmediķis Augusts Kirhenšteins, arhitekts Artūrs Krūmiņš, agrārzinātnieks Paulis Lejiņš, purvu pētnieks Pēteris Nomals, agrārķīmiķis Jānis Peive, medik̦is Pauls Stradin̦š, biok̦īmik̦is Aleksandrs Šmits, arhitekts Ernests Štālbergs, rakstnieks un literatūrzinātnieks Andrejs Upīts, padomju nomenklatūras darbinieks Pēteris Valeskalns. Lielākā daḷa no tiem bija pirmskara LU profesori (8 no 13), vien četri - iebraucēji no PSRS, Krievijas latvieši. ${ }^{50}$

49 Jānis Stradiṇš, "Staļina režīma attieksme pret Latvijas zinātniekiem un akadēmiskajām aprindām," no Okupètā Latvija, 1940-1990: Latvijas Vēsturnieku komisijas 2005. gada pètījumi = Occupied Latvia, 1940-1990: research of the Commission of the Historians of Latvia 2005, Latvijas Vēsturnieku komisijas raksti, 19. sēj. (Rīga: Latvijas vēstures institūta apgāds, 2007), 408-448.

50 Jānis Stradin̦š, Latvijas Zinātņu akadēmija: izcelsme, vēsture, pārvērtības, 118-148; Jānis Stradiņš, Dzintra Cēbere, "Latvijas Zinātņu akadēmijas veidošanās: zinātniskie un sabiedriski politiskie aspekti," 90-114; Konstantīns Karulis, "Pirmie akadēmiķi. Atmiṇu ieskicējums," Latvijas Zinātņu Akadēmijas Vēstis. A daḷa, 1 (1996): 41-55. 
Pirmā Latvijas PSR Zinātṇu akadēmijas pilnsapulce notika 1946. gada 14. februārī (to uzskata par LZA dibināšanas datumu), par akadēmijas pirmo prezidentu ievēlēja agrārzinātnieku (liellopu selekcijas un ganību speciālistu) Pauli Lejiṇu, kurš baudīja cieņu un uzticību Latvijas sabiedrībā. ${ }^{51}$

Turpmākajās akadēmiķu vēlēšanu reizēs (līdz 1990. gadam) tika ievēlēti citi zinātnieki, zinātnisku skolu veidotāji, piemēram, ķīmiķi Solomons Hillers, Edmunds Lukevics, Gunārs Čipēns, Lidija Liepiņa, Gustavs Vanags, Afrēds Ieviņšs, Marǵeris Līdaka, Emīlija Gudriniece, Ojārs Neilands, biologi Rita Kukaine, Mārtiņš Beķers, Elmārs Grēns, Uldis Viesturs, fizik̦i Igors Kirko, Jānis Lielpēters, Kurts Švarcs, mehānikas un inženierzinātņu pārstāvji Aleksandrs Mālmeisters, Kārlis Plaude, Alfons Kroǵers, Egons Lavendelis, humanitāro zinātṇu pārstāvji Jānis Zutis, Aleksandrs Drīzulis, Vilis Samsons, Valentīns Šteinbergs.

Tomēr būtiskāk bija tas, ka Latvijas PSR ZA veidoja ne tikai individuāli zinātnieki, bet vienlaikus tā bija prāvu pētniecisku institūtu (līdz pat 500-800 darbinieku) kopa. 1985. gadā ZA institūtos strādāja 7623 cilvēki, t. sk. 1598 zinātniskie darbinieki (aptuveni 11,5\% republikas zinātnieku), taču te bija koncentrēti nozīmīgākie fundamentālākie pētījumi un pētniecībai atvēlētie resursi. ${ }^{52}$ Formāli Latvijas PSR ZA skaitījās neatkarīga no PSRS ZA, taču pēdējā koordinēja visu savienoto republiku zinātṇu akadēmiju darbību, pārraudzīja un būtībā reglamentēja arī Latvijas PSR ZA darbību.

\section{Modernu virzienu veidošanās Latvijas zinātnē 20. gs. otrajā pusē}

Veidošanās sākumā Latvijas PSR ZA galvenokārt pētīja ar republikas pēckara atjaunošanu saistītās problēmas, Latvijas dabas bagātības un energêtiskos resursus, mežsaimniecību un vietējās tautsaimniecības attīstību. Vērtējot šos darbus, PSRS ZA prezidents, ievērojamais fiziķis Sergejs Vavilovs, 1948. gadā atzina, ka, "šķiet, 90 \% darbu ir ar gluži praktisku raksturu [..], taču nav jāaizmirst arī tas, ko saucam par lielo, principiālo zinātni”. Pēc diviem gadiem Vavilovs jau pozitīvi vērtēja arī šajā ziņā Latvijā paveikto. ${ }^{53}$

51 Kārlis Pētersons, red., Paulis Lejiņš dzīvē un darbā (Rīga: Zinātne, 1983).

52 Pēteris Jērāns un Sigurds Ziemelis, red., Latvijas Padomju enciklopēdija (Rīga: Galvenā enciklopēdiju redakcija, 1984), 5.2: 450.

53 Stenogrammy zasedanii sessii Soveta po koordinatsii nauchnoi deiatelnosti AN soiuznykh respublik (mai 1948 g.). Latvijas Zinātņu Akadēmijas Centrālais arhīvs, 1. fonds, 1. apraksts, 77. lieta, 253. 1p. 
Pirmajos Latvijas PSR Zinātṇu akadēmijas pastāvēšanas gados Arvīds Kalniņš veiksmīgi attīstīja paša dibināto Mežsaimniecības problēmu (tagadējo Koksnes ķīmijas) institūtu. ${ }^{54}$ Tur enerǵiskais ķīmiķis Solomons Hillers izstrādāja pirmos medicīniskos preparātus (PASS un furacilīnu) un samērā drīz, 1957. gadā, lika pamatus Latvijas Organiskās sintēzes institūtam (OSI). Šis institūts uzreiz guva ievērību PSRS mērogos un joprojām ir vērienīgākais un pētnieku skaita ziņā lielākais zinātniskais institūts arī mūsdienu Latvijā. Tajā sintezēti oriǵinālie un efektīvie medicīnas preparāti ftorafürs (tegafurs), furagīns (furamags), solafürs (furasols), remantadīns, mildronāts (ražošanā kopš 1984. gada) u. c., kurus joprojām turpina ražot. Institūtā savulaik tapuši $25 \%$ no visiem PSRS radītajiem medikamentiem, ap to izveidotas ražošanas bāzes Rīgā un Olainē, kas turpina strādāt arī mūsdienu Latvijā (Grindeks, Olainfarm). Pēc ZA ierosmes tika radīta ķ̄imiski farmaceitiskā industrija, kas ir būtiska Latvijas vērtība arī mūsdienās. ${ }^{55}$

Fizikas institūtā tika izvērsti pētījumi magnētiskajā hidrodinamikā, kas vēlāk l̦āva nonākt pie būtiska atklājuma (dinamo efekta radīts magnētiskais lauks, ar ko tika pierādīta hipotēze par kosmisko objektu un kosmiskās telpas magnētiskā lauka izcelšanās mehānismu). ${ }^{56}$ Attīstījās Augusta Kirhenšteina iedibinātais Mikrobiologijas institūts (dibināts 1946. gadā uz LU Serumstacijas bāzes), kur Rita Kukaine, Aina Muceniece u. c. zinātnieki veica pētījumus virusoloǵijā, poliomielīta un leikožu pētniecībā, savukārt Mārtiņš Beķers - par lizīna u. c. biotehnoloǵisko ieguvi. Atzīstams ir Neorganiskās ķ̄imijas institūta devums grūti kūstošu savienojumu plazmas sintēzē (Tālis Millers), metālu korozijas mehānismu un elektroķīmiskās ekstrakcijas pētījumos (Lidija Liepiņa, Bruno Puriņš).

54 Jānis Zandersons, sast., Arvīds Kalniņš dż̄vē un darbā (Rīga: Zinātne, 1992); Milda Pormale, Zaḷais patvērums: akadēmiķis Arvīds Kalniņš viņa arhīva materiālos un manās atmiņās: akadēmiķa Arvīda Kalniņa dzīvesstāsts (Ķeipene: Divpadsmit, 2012).

55 Ianis Stradyn, sost., S. A. Giller. Zhizn i nauchnaia deiatelnost (Riga: Zinatne, 1982); Jānis Stradiņš un Osvalds Pugovičs, sast. un red., Latvijas Organiskās sintēzes institūts 50. Pirmais pusgadsimts un nākotnes meti (R̄̄ga: Zinātne, 2007); Jānis Stradiṇš, red., No Grindeļa lìdz mūsdienām: apceres par farmācijas tradīcijām un jaunu àrstniecības preparātu meklējumiem Latvijā, 165-272; Mariia Shimanskaia i Ianis Stradyn, "Akademiia Nauk Latviiskoi SSR i stanovlenie khimicheskogo nauchnoproizvodstvennogo kompleksa v Olaine," Izvestiia Akademii nauk Latviiskoi SSR 11 (1986): 36-44.

56 Latvijas Zinātņu akadēmijas gadagrāmata, 2000 (Rīga: Zinātne, 2000), 123. 
1961. gadā tika atklāts Salaspils kodolreaktors, pirmais un vienīgais pētniecības reaktors Baltijas republikās, kur attīstījās kodolfizika un radiācijas fizika (slēgts 1998), Baldonē 1958. gadā izveidota Astrofizikas laboratorija (vēlāk - ZA Radioastrofizikas observatorija), gūti svarīgi rezultāti sarkano milžu zvaigžņu pētniecībā. ${ }^{57}$

Ar militāri rūpniecisko kompleksu bija cieši saistīts Polimēru mehānikas institūts (dib. 1963. gadā Aleksandra Mālmeistera vadībā) un Elektronikas un skaitļošanas tehnikas institūts (dib. 1960). PSRS mērogos nozīmīgs bija ZA ieguldījums padomju kosmonautikas attīstībā - siltumizolācijas materiāli un to uzklāšana uz raķešu un Buran tipa kosmisko retūrkuǵu korpusu virsmas (Arnolds Alksnis u. c.), termoregulējošo pārklājumu sastāvs un uznešana uz kosmosā sūtāmā objekta ārējās čaulas ("baltie pārklājumi”) vai liekā siltuma novadīšanai no satelīta apkārtējā vidē (“melnie pārklājumi”), grūti kūstošu karbīdu, nitrīdu, borīdu u. c. plazmas ķīmiskās sintēzes Buran kosmosa kuǵiem (Tālis Millers), arī kompozītie materiāli raķetēm. Š̄is lietišķās izstrādes skaitījās stingri slepenas. ${ }^{58}$

1958. gadā Latvijas PSR ZA rīcībā tika nodota ZA augstceltne, kurā izvietojās akadēmijas vadība, izdevniecība "Zinātne" un vairāki pētnieciskie institūti. Ārpus Rīgas centra un pilsētas pievārtē - Salaspilī, Baldonē - izveidojās akadēmiskās pilsētiņas ar plašu institūtu un konstruktoru biroju tīklu. ZA rīcībā bija vairākas eksperimentālas rūpnīcas, no kurām OSI Eksperimentālā rūpnīca vēlāk pārtapa par firmu Grindeks (nosaukums no pirmā latviešu farmaceita D. H. Grindel̦a vārda).

Mūsdien̄̄gi pētniecības virzieni veidojās ne tikai ZA institūtos, bet arī Latvijas vadošajās universitātēs. Latvijas Valsts universitātes (LVU) sastāvā dibinātajā Cietvielu fizikas institūtā (1978) tika izvērsti jonu kristālu, stiklveida materiālu, segnetoelektrisku un amorfu pusvadītāju pētījumi un radās zinātniskās skolas segnetoelektriķu un pusvadītāju fizikā (Voldemārs Fricbergs, Juris Zaķis, Andrejs Siliņš, Arnis Šternbergs,

57 Talivaldis Viltsinsh i Silviia Zarinia, sost., Vilis Samson, red., Akademiia nauk Latviiskoi SSR, 1946-1970 gg. (Riga: Zinatne, 1971); Laura Kalinka, sast., Vilis Samsons, red., Latvijas PSR Zinātņu akadēmija (Rīga: Zinātne, 1977); Laura Kalinka, sast., Latvijas PSR Zinātņu akadēmija, 1946-1981 (Rīga: Zinātne, 1981); Poiski i otkrytiia: Populiarnye ocherki ob Akademii nauk Latviiskoi SSR (Riga: Zinatne, 1970); Valdis Gavars, sast., Salaspils zinātniskā kodolreaktora 50 gadi, 1961-2011: atmiņas, pētījumi, sasniegumi (Rīga: Zinātne, 2010).

58 Tālivaldis Millers, "Neorganiskās ķīmijas institūta zinātnieku ieguldījums kosmosa tehnoloǵiju un materiālu izpētē,” Zvaigžņotā Debess (vasara 2011): 11-13. 
Linards Skuja u. c.). ${ }^{59}$ Tagadējais LU Matemātikas un informātikas institūts (dib. 1959. gadā kā LVU Skaitļošanas centrs; Eižens Āriņš, Jānis Bārzdiņš, Rūsiņš Mārtiņš Freivalds u. c.) izveidojis Latvijā modernās datorzinātnes un informāciju tehnologijijas, radījis jaunas pieejas varbūtisko algoritmu matricu reizinājuma pārbaudei (R. M. Freivalds). Atzīmējami LVU sasniegumi mākslīgo Zemes satelītu novērošanas sistēmas izveidē, mazo planētu orbītu aprēķināšanā, skaițu teorijas veidošanā u. c.

Atjaunotajā Rīgas Politehniskajā institūtā, izvēršot Gustava Vanaga pētījumus ciklisko diketonu k̦īmijā, Ojārs Neilands ieguvis jaunus organiskos materiālus molekulārajai elektronikai un optikai (sadarbībā ar fiziķi Edgaru Imantu Siliņu un Valdi Kamparu), Raimonds Valters pētījis virknes-cikla izomēriju. 1950. gadā izveidotajā Rīgas Medicīnas institūtā (uz tā bāzes 1998. gadā tapusi Rīgas Stradiṇa universitāte) šajā laikposmā atzīmējami Makša Bel̦enkija pētījumi farmakologijāā un Anatolija Bḷugera pētījumi hepatoloǵijā.

Atgriežoties pie Organiskās sintēzes institūta (OSI), jāakcentē oriǵinālie pētījumi heterociklu, nukleozīdu un nukleotīdu ķīmijā (Gunārs Duburs, Ivars Kalviņš, Marğeris Līdaka), bioloǵiski aktīvo silīcijorganisko un germānijorganisko savienojumu ķīmijā (Edmunds Lukevics, Mihails Voronkovs), peptīdu k̦īmijā un farmakoloğijā (Gunārs Čipēns, Vija Kluša), molekulārajā elektroķīmijā (Jānis Stradiņš), kodolmagnētiskās rezonanses pētījumos (Edvards Liepiņš, Ēriks Kupče) u. c. Starptautisku rezonansi guva Latvijā veiktie pētījumi molekulārajā bioloǵijā un gēnu inženierijā, kuras pamatlicējs Latvijā ir Elmārs Grēns (kopā ar Paulu Pumpēnu). Arī šie darbi aizsākti 1969. gadā OSI ietvaros, bet kopš 1991. gada nozare koncentrēta Latvijas Biomedicīnas pētījumu un studiju centrā. ${ }^{60}$ LZA attīstījās arī hidrobioloǵija un hidroekoloǵija, tika izveidota "Latvijas Sarkanā grāmata" par apdraudētām augu, sēņu un dzīvnieku sugām (1. izd. 1985, 2. izd. 1996-2003; Gunārs Andrušaitis u. c.).

Latvijā agrāk netradicionāli zinātnes virzieni veidojās savam laikam pietiekami modernā līmen̄̄, finansiāli tika atbalstīti pētnieciskie projekti,

59 Andris Šternbergs, iev., Latvijas Universitātes Cietvielu fizikas institūts (Rīga: Latvijas Universitātes Cietvielu fizikas institūts, 2013); Jānis Jansons, No Latvijas Universitātes Fizikas institūta (1919) līdz Cietvielu fizikas institūtam (1978) (Rīga: LU Akadēmiskais apgāds, 2016).

60 Elmārs Grēns, Ab initio jeb kā mēs Latvijā izveidojām molekulāro biologiju (Rīga: Zinātne, 2015). 
īpaši tie, kuri bija saistīti ar PSRS militāri rūpniecisko kompleksu. Pētniecība Padomju Latvijā bija daudz vērienīgāka nekā pirmskara Latvijā, strauji pieauga zinātnisko darbinieku skaits (1913. gadā - 50, 1940. gadā - 1129, 1980. gadā - 12 585, 1990. gadā - 17 733), tāpat pieauga zinātnes prestižs sabiedrībā, īpaši jaunatnes vidū. ${ }^{61}$ Lai gan kopš 60 . gadu vidus tika īstenota Latvijas zinātnes integrēšanās "vienotā padomju zinātnē", taču zinātnieku emigrācija uz Maskavu, L̦eņingradu, Sibīrijas centriem bija niecīga, latviešu zinātnieku mentalitātē bija izteikts vietējais patriotisms, zināma norobežošanās no Krievijas ("regional identity under Soviet rule", kā to trāpīgi formulēja Andrejs Dītrihs Lēbers). Starp citu, Rīga pati bija kḷuvusi par vērien̄̄gu starptautisku konferenču rīkošanas vietu ar plašu ārzemnieku līdzdalību. Īpaši nozīmīgs bija 7. IUPAC simpozijs par dabasvielu ķīmiju ar 1800 dalībniekiem, kur Nobela prēmijas laureāts Hars Gobinds Korana pirmoreiz pasaulē ziṇoja par mākslīgā gēna sintēzi (Rīga, 1970). ${ }^{62}$

LPSR ZA izdeva ne tikai "Latvijas PSR Zinātņu Akadēmijas Vēstis”, bet arī piecus "vissavien̄̄bas" zinātniskos žurnālus, no kuriem četri tika tulkoti angḷ valodā un izdoti ASV "from cover to cover". To skaitā "Chemistry of Heterocyclic Compounds" bija vien̄̄gais Jūdžina Gārfilda "Science Citation Index" avotu bāzē iekḷautais Baltijas republikās izdotais žurnāls. ${ }^{63}$ Zinātnē dominēja krievu valoda, lai gan daudzas Latvijas ķīmiķu un fiziķu monogrāfijas izdotas ārzemēs arī angl̦u valodā. Sakari ar Rietumvalstīm bija ierobežoti un stingri pārraudzìti, nozīmīgākās pētījumu un izstrādņu programmās valdīja slepenība, daudziem autoritatīviem zinātniekiem bija liegts piedalīties konferencēs ārpus PSRS. Institūtiem bija grūti iegādāties modernu pētniecisku aparatūru, ko ZA sistēmā gan daḷēji novērsa, izmantojot "cieto valūtu" (OSI visai ZA pelnīja ar S. Hillera izgudrotā pretvēža preparāta tegafūra eksportu uz Japānu).

61 Tālivaldis Vilciņš, Profesiju prestižs un profesiju izvēle mūsdienās (R̄̄ga: Zinātne, 1968); Talivaldis Viltsinsh, "Nauka i uchenye v predstavleniiakh molodezhi: prestizh professii uchenykh," Izvestiia Akademii nauk Latviiskoi SSR, 8 (1987): 49-62; Talivaldis Viltsinsh, "Lichnost uchenogo v predstavleniiakh vypusknikov srednikh shkol Latviiskoi SSR,” Izvestiia Akademii nauk Latviiskoi SSR, 1 (1988): 70-80.

62 The Chemistry of Natural Products, 7: plenary lectures presented at the $7^{\text {th }}$ International Symposium on the Chemistry of Natural Products held at Riga, USSR, 22-27 June 1970. London: Butterworths, 1971 (Pure and Applied Chemistry 25, no. 1 (1971)).

63 Jānis Stradin̄š, Latvijas Zinātņu akadēmija: izcelsme, vēsture, pārvērtības, 303; Ianis Stradyn, "U istokov zhurnala "Khimiia geterotsiklicheskikh soedinenii"," Khimiia geterotsiklicheskikh soedinenii, 1 (2005): 15-20. 


\section{Humanitārās un sociālās zinātnes Padomju Latvijā}

Humanitārajās un sociālajās zinātnēs iespējas bija daudz ierobežotākas nekā eksaktajās zinātnēs ideoloǵisku un politisku spaidu, dogmatisku aizspriedumu dēl (cīnna pret "buržuāziskā nacionālisma” izpausmēm, diskusiju brīvības trūkums, "buržuāzisko teoriju” kritika). ZA sistēmā kopš 1946. gada darbojās Valodas un literatūras institūts, Vēstures institūts, Ekonomikas institūts, vēlāk arī Filozofijas un tiesību institūts (dib. 1981). Pēc padzī̌sanas no darba LVU (1950) akadēmijā darbību turpināja valodnieks J. Endzelīns, kuru gan asi kritizēja (īpaši LKP CK sekretārs Arvīds Pelše), bet kurš tomēr spēja laist klajā fundamentālās "Latviešu gramatikas" pirmizdevumu latviešu valodā (1951) un saņemt par to L̦eņina prēmiju (1959), savukārt pēc Endzelīna nāves iznāca reprezentatīva viņa darbu izlase (4 sējumos, 6 grāmatās, 1971-1982). Daudziem Endzelīna skolnieku veiktiem pētījumiem par dialektolog̣iju, toponīmiku, valodas vēsturi utt. ir paliekoša vērtība (Artūrs Ozols, Marta Rudzīte, Vallija Dambe, Daina Zemzare, Antons Breidaks, Aina Blinkena, Rasma Grīsle u. c.). ${ }^{64}$

Literatūrzinātnē īpaši atzīmējams ir Raiņa Kopoto rakstu lielizdevums 30 sējumos (1977-1986), kur pirmoreiz akadēmiski sakopota un zinātniski komentēta šì latviešu dzejnieka un domātāja vispusīgā radošā darbība. ${ }^{65}$ Latviešu literatūras, teātra un mākslas vēstures jomā šajā laikā izvirzījās Jānis Kalniņš, Kārlis Kundziņš, Viktors Hausmanis, Lilija Dzene, Vera Vāvere, Arnolds Klotiņš u. c.

Latvijas historiogrāfijā nozīmīgākā personība bija Jānis Zutis, kurš pēc ierašanās no Maskavas spēja pulcēt ap sevi nedaudzos pirms kara strādājušos vēsturniekus (Marǵeris Stepermanis, Teodors Zeids) un izaudzināt jaunu vēsturnieku paaudzi (Heinrihs Strods, Maksims Duhanovs, Vasilijs Dorošenko). Jaunāko laiku vēsture gan bija pārmērīgi politizēta laikmeta koncepciju garā (Aleksandrs Drīzulis u. c.), kas latviešu sabiedrisko domu kritiski noskaņoja pret vēstures zinātni vispār. ${ }^{66}$

64 Jānis Endzelīns, Latviešu gramatika (Rīga: LVI, 1951); Jānis Endzelīns, Darbu izlase, 4 sēj. (Rīga: Zinātne, 1971-1982); Andrejs Bankavs un Ilga Jansone, Valodniecība Latvijā: fakti un biogrāfijas (Rīga: LU Akadēmiskais apgāds, 2010).

65 Jānis Rainis, Kopoti raksti, 30 sēj., galv. red. Vilis Samsons (Rīga: Zinātne, 1977-1986); Jānis Rainis, Runas un intervijas, atb. red. Viktors Hausmanis (Rīga: Zinātne, 1993).

66 Arvīds Drīzulis un Teodors Zeids, red., Akadēmiķis Jānis Zutis (Rīga: LPSR ZA izdevniecība, 1964); Ianis Zutis, Ocherki po istoriografii Latvii, ch. 1 (Riga: Latgosizdat, 1949); Anatolii Biron i Vasilii Doroshenko, Sovetskaia istoriografiia Latvii 
Nozīmīgākie sasniegumi tika gūti arheolog̣ijā, ko veicināja lielo hidroelektrostaciju būve. Lai nomierinātu sabiedrisko domu, tika finansēta arheoloǵiskā izpēte Daugavas senlejā pie Salaspils, Ikšksiles, Sēlpils u. c. Izpēti veica arī Vecrīgā, Turaidā, pie Burtnieku ezera, Lubānas klānos. Tas l̦āva izaugt augsti kvalificētu arheologu paaudzei (Ēvalds Mugurēvičs, Jānis Graudonis, Elvīra Šnore, Andris Caune, kuru pētījumi guva speciālistu ievērību arī ārpus Latvijas). Jau pēc Latvijas neatkarības atgūšanas tika iedzīvināti vērien̄̄gi piḷu rekonstrukcijas projekti, kas kḷuva par šo darbu rosinātāju un veicēju mūža pieminekli (Turaidas pils komplekss Jānim Graudonim un Āraišu pils rekonstrukcija Jānim Apalam). ${ }^{67}$ Nepārvērtējams ir Imanta Lancmaņa veikums Rundāles pils un parka izpētē un atjaunošanā, kas aizsākās jau 60. gados.

Pēc grāmatas "Rīgas vēsture" izdošanas trīs sējumos (1978-1980) tika iesākta Johana Kristofa Broces Rīgas un Vidzemes 18. gs. zīmējumu un aprakstu izpēte un sagatavošana izdošanai (Teodors Zeids, Meta Taube, piesaistot jaunos vēsturniekus). J. K. Broces krājuma četri sējumi gan izdoti tikai neatkarības gados ilgākā laika posmā (1992-2007). ${ }^{68}$

Filozofijas un tiesību institūtā veidojās jauna pētnieku paaudze, kas jau padomju režīma apstāklı sos spēja pētît filozofijas problēmas modernā līmen̄i, izdot filozofijas klasiķu darbus latviešu valodā, sniegt objektīvu pārskatu par sabiedriskās domas un reliǵijas vēsturi Latvijā (Vilnis Zariņš, Maija Kūle, Ella Buceniece u. c.).

Tādējādi šajā nelabvēlīgajā laikmetā Latvijā arī humanitārajās zinātnēs pamazām veidojās rietumnieciski domājošu cilvēku paaudze, kas atjaunotās Latvijas apstākḷos bija gatava veikt pētījumus par latviešu valodu, Latvijas vēsturi, kultūras, mākslas, teātra un literatūras attīstību.

(Riga: Zinatne, 1970); Regina Greitiane, sost., Anatolii Biron, red., Istoricheskaia nauka Sovetskoi Latvii na sovremennom etape (Riga: Zinatne, 1983); sk. arī: Ilgvars Misāns, Klio Latvijā: raksti par historiogrāfijas problēmām (Rīga: LU Akadēmiskais apgāds, 2012).

67 Anatolijs Bīrons, red., Latvijas PSR arheologija (Rīga: Zinātne, 1974); Ēriks Mugurēvičs, "Latvijas vēstures institūta arheologu darbs piecdesmit gados," Latvijas Vēstures Institūta Žurnāls, 4 (1995): 48-91; Andris Caune, "Latvijas vēstures institūta ieguldījums Rīgas arheoloǵijas izpētē 1938.-1996. gadā," Latvijas Vēstures Institūta Žurnāls, 4 (1995): 92-102; Jānis Graudonis, Turaidas pils, 2 sēj. (Rīga: Turaidas muzejrezervāts, 2003); Jānis Graudonis, Mana dzīve atminnu gaismāa: arheologa dzīvesstāsts (Rīga: Zinātne, 2008); Jānis Apals, Āraišu ezerpils: rakstu izlase un draugu atmiñas, sast. Andris Caune un Zigrīda Apala (Rīga: Latvijas vēstures institūta apgāds, 2012).

68 Johans Kristofs Broce, Zīmējumi un apraksti, 4 sēj. (Rīga: Zinātne; Latvijas vēstures institūta apgāds, 1992-2007). 


\section{Zinātne Latvijā pēc neatkarības atgūšanas}

Ar valstiskās neatkarības atgūšanu 1990.-1991. gadā būtiski mainījās situācija arī Latvijas zinātnē. Beidzās tās funkcionēšana lielvalstī (bij. PSRS), bija jāsāk darboties nelielā valstī ar gluži citām finanšu iespējām un prioritātēm. Turklāt totalitāru plānveida ekonomiku (arī "plānojamu" zinātni) nomainīja demokrātiska iekārta ar garantētu pētniecisku brīvību. Mainījās pētniecības finansēšanas sistēma. Pēc Latvijas Zinātnes padomes (LZP) izveidošanas jau no 1991. gada sāka atbalstīt labākos zinātniskos projektus neliela apjoma finansējumu (grantu) formā. ${ }^{69}$ Kompleksas pētījumu programmas, vismaz līdz 1996. gadam, vispār netika finansētas, un tikai kopš 2005. gada pakāpeniski konkursa kārtā sāka atdzīvināt Latvijai aktuālas valsts nozīmes pētniecības programmas (kas pašreiz saņem no Latvijas valsts zināmu pētniecībai atvēlētā nacionālā budžeta daļu).

Radās daudz plašākas iespējas iesaistīties starptautiskā zinātnieku kopībā, kḷuva intensīvāka sadarbība ar Rietumeiropas un Ziemel̦eiropas valstīm, ASV, pat Taivānu, tapa kopēji projekti ar šo valstu zinātniekiem, pieauga publikāciju skaits starptautiskajos izdevumos angḷu valodā. 1992. gadā Dānijas Zinātnes padomes organizētā starptautiskā ekspertīze 30 \% izvērtēto projektu atzina par teicamiem (īpaši fizikā, informātikā, inženierzinātnēs, ķīmijā) un ieteica Latvijas zinātni turpmāk veidot pēc Ziemel̦valstu model̦a, pētniecību tuvināt augstākajai izglītībai un vietējai tautsaimniecībai, iesaistīt starptautiskā apritē. ${ }^{70}$

1992. gadā notika Latvijas Zinātņu akadēmijas pārveide, jaunajā Hartā pasludinot to par nacionālas nozīmes zinātnes institūciju, kura sastāv no ievēlētiem Zinātṇu akadēmijas locekḷiem un kuru subsidē valsts. 1997. gadā Hartu (nedaudz modificētā veidā) vienbalsīgi apstiprināja Saeima. ${ }^{71}$ Pārveidotajai ZA vairs nebija administratīvu funkciju, tās sastāvā vairs neietilpa pētnieciskie institūti. Tie tika iekḷauti lielajās Rīgas universitātēs (galvenokārt LU) vai arī turpināja darbību kā neatkarīgi

69 Jānis Stradiņš, “Zinātne lielvalstī un mazā valstī: Latvijas piemērs,” Latvijas Zinātņu Akadēmijas Vēstis. A daḷa, 1 (1996): 18-24; salīdzinājumam sk.: Helle Martinson, The Reform of R\&D System in Estonia (Tallinn: Estonian Science Foundation, 1995).

70 Latvian Research: an International Evaluation (Copenhagen: The Danish Research Councils, 1992); Juris Ekmanis, "Latvijas zinātnes starptautiskā ekspertīze," Latvijas Zinātņu Akadēmijas Vēstis. A daļa, 3 (1993): 39-40.

71 “Latvijas Zinātņu akadēmijas Harta,” Latvijas Zinātņu akadēmijas gadagrāmata, 1999 (R̄̄ga: Zinātne, 1999), 11-14; Jānis Stradiņš, Latvijas Zinātņu akadēmija: izcelsme, vēsture, pārvērtības, 576-579. 
zinātniskie institūti (piemēram, Latvijas Organiskās sintēzes institūts, Latvijas Valsts koksnes ķīmijas institūts, Elektronikas un datorzinātņu institūts, Latvijas Biomedicīnas pētījumu un studiju centrs). Zinātṇu akadēmijas un tās locekḷu pienākumos ietilpa ekspertu funkcijas pētniecībā un zinātnes stratēgijāâ, promocijas darbu izvērtēšana, valsts emeritēto zinātnieku aprūpe, latviešu zinātniskās terminoloǵijas pilnveide un sakārtošana (arvien vairāk publikāciju latviešu valodā, īpaši humanitārajās zinātnēs), zinātniskās izcilības novērtēšana, ievēlot jaunus ZA locekḷus, piešksirot LZA Lielās medaḷas (kopš 1993) un zinātnieku vārdā nosauktās balvas. Strauji pieauga LZA ievēlēto 1̄steno locekļu, korespondētājlocekḷu, goda locekḷu un ārzemju locekḷu skaits (2016. gadā LZA ir 400 locekḷu un 82 goda doktori, t. sk. 122 īstenie locekḷi - akadēmiķi; locekḷu skaita ziṇā tā ir lielākā ZA Baltijas valstīs). LZA ir kluvusi par prominentu zinātnieku kopu, kas pārstāv Latviju starptautiskajā zinātnieku pasaulē, dažādās zinātnieku organizācijās. ${ }^{72}$

Kopš 1990. gada iezīmējās reāla integrācija ar latviešu diasporā (trimdā) strādājošiem zinātniekiem, kuri tika ievēlēti par LZA ārzemju vai goda locekḷiem (piemēram, Edgars Dunsdorfs, Aleksis Dreimanis, Nikolajs Balabkins, Juris Hartmanis, Dainis Draviņš, Vaira V̄îse-Freiberga, Imants Freibergs, Andrievs Ezergailis, Edvīns Vedējs, Andris Padegs, Jānis Krēsliņš, Juris Upatnieks, Jānis Kḷaviņš, Bertrams un Kristaps Zariņi, Kristaps Juris Keggi, Magda Štaudingere-Voita, Pēteris Lejiņš, Haralds Biezais, Velta Rūkse-Draviņa, Valters Nollendorfs, Gunārs Birkerts, Dītrihs Andrejs Lēbers), vai Latvijas universitāšu goda doktoriem. Viņi sniedza lielu palīdzību zinātnei Latvijā, īpaši pirmajos, grūtajos atjaunotās neatkarības gados, veicināja jauno latviešu zinātnieku, arī mediķu, studijas ārzemēs. ${ }^{73}$ Vienojoša nozīme bija pasaules latviešu zinātnieku kongresiem, īpaši pirmajam, kuru organizēja jau 1991. gada jūlijā (2. un 3. kongress notika attiecīgi 2001. un 2011. gadā, savukārt 4. kongress - 2018. gada jūnijā). ${ }^{74}$

72 Latvijas Zinātņu akadēmijas gadagrāmata, 1992[-2018], http://www.lza.lv/index. php?option=com_content\&task=blogcategory\&id=18\&ltemid=57.

73 Jānis Stradiñš, "Latvian science in exile and its reintegration with science in Latvia," Proceedings of the Estonian Academy of Sciences. Humanities and Social Sciences, 44, no. 2 (1995): 129-137.

74 Vispasaules latviešu zinātņu kongress, Rīga, 1991. gada 12.-17. jūlijā: dalībnieku referāti, biogrāfijas, adreses, 8 sēj. (Rīga: b. i., 1991). Par Pasaules latviešu zinātnieku 2. kongresu sk.: Latvijas Zinātņu Akadēmijas Vēstis. A daḷa, $3 / 4$ (2001); par 
Iepriekšminētais, protams, deva pozit̄̄vus impulsus Latvijas zinātnes transformācijai, reorientācijai no Eirāzijas zinātniskās telpas uz Eiropas telpu. Diemžēl darbošanās nelielas un samērā trūcīgas valsts sastāvā, īpaši pirmajā neatkarības desmitgadē, lika samazināt pētniecības apjomu un fundamentālo pētījumu īpatsvaru.

90. gados l̦oti daudzās zinātnes un izstrāžu jomās valdīja īsts sabrukums. Līdzīgi tam, kā beidza darbību industrijas milzeņi, tostarp slavenā rūpnīca VEF, beidza pastāvēt arī Latvijā funkcionējošie lielie PSRS pakḷautības lietišķie institūti: Jūras ǵeolog̣ijas institūts VNIMORGEO, Vagonbūves institūts, Bioķīmisko reaǵentu institūts Olainē u. c. Bijušie ZA institūti, kā minēts iepriekšs, 1993.-1998. gadā iekḷāvās Rīgas universitāšu (galvenokārt LU) sastāvā ar ievērojami samazinātu darbinieku skaitu. Sākās zinātnieku aizplūde no pētniecības institūcijām, sākumā kā iekšejēa emigrācija (pāreja uz privātstruktūrām, valsts un pašvaldību iestādēm), taču drīz vien iezīmējās arī Latvijas zinātnieku t. s. trešā emigrācija (uz Zviedriju, Vāciju, Lielbritāniju, ASV, Franciju, Izraēlu u. c.).

Zinātnē nodarbināto kopskaits Latvijā samazinājās no 17733 (1990) līdz 3072 (1995) (tiesa, dati nav gluži salīdzināmi, jo Latvijas Republikas likumi par zinātnieku uzskata personu ar doktora grādu, kamēr agrāk tādi skaitījās visi pētniecībā iesaistītie darbinieki). 1990. gadā Latvijā strādāja 3710 graduētu pētnieku, savukārt 1995. gadā - 1510 (zinātņu doktoru gan bija vairāk, taču prāva to daḷa bija pensijā vai pētniecībā vairs nedarbojās). ${ }^{75}$ Zinātnieki pamazām kḷuva par mazāk prestižu sabiedrības daḷu ar zemu atalgojumu. ${ }^{76}$

3. kongresu: Apvienotais Pasaules latviešu zinātnieku 3. un Letonikas 4. kongress "Zinātne, sabiedrība un nacionālā identitāte". Rīga, 2011. gada 24.-27. oktobris. Plenārsēžu materiāli (R̄̄ga: Latvijas Zinātṇu akadēmija, 2012).

75 BIRTI Zinātnes, tehnoloǵiju un inovācijas stratēǵija lietpratīgai specializācijai 2014.2020. gadam (prezentēta 2013. gada 28. augustā). (Rīga, 2013), 35; Jānis Stradiṇš, "Latviešu zinātnieki Latvijā un ārzemēs," no Apvienotais Pasaules latviešu zinātnieku 3. un Letonikas 4. kongress "Zinātne, sabiedrība un nacionālā identitāte," 54; Jānis Kristapsons, "Latvijas zinātne skaitḷos," no Apvienotais Pasaules latviešu zinātnieku 3. un Letonikas 4. kongress "Zinātne, sabiedrība un nacionālā identitāte," 490-492; Janis Kristapsons and Erika Tjunina, "Changes in the Latvian Research System," Science and Public Policy 22, no. 5 (1995): 305-312; Akademicheskie instituty v usloviiakh transformatsii: rezultaty sravnitelnogo issledovaniia po 12 stranam Tsentralnoi i Vostochnoi Evropy (Moskva: Tcentr issledovanii i statistiki nauki, 1997), 121-144.

76 Ilze Koroḷova, Inta Mieriṇa un Ritma Rungule, Profesiju prestižs un izvēle jauniešu vidū: divu paaudžu salīdzinājums (Rīga: LU Akadēmiskais apgāds, 2014). 
Dramatiskās pārmaiņas Latvijas un arī abu pārējo Baltijas valstu zinātnē un tehnoloǵiju izstrādēs 1989.-2003. gadā izanalizētas Jāṇa Kristapsona un līdzautoru grāmatā "Baltic R\&D Systems in Transition". ${ }^{77}$

Šīs pārmaiņas izraisīja apstāklis, ka zinātne pārgāja no darbības lielvalstī uz funkcionēšanu mazā valstī ar atbilstošu finansējumu, kur tradicionāli dominē reǵionālās un nacionālās identitātes uzturēšanai pievērstās disciplīnas. Arī Latvijā demokratizāciju zinātnē diemžēl pavadīja zinātnes finansējuma kritums gan kopējā valsts budžetā, gan absolūtos skaiţ̦os, tematiku revīzija, eksakto un dabaszinātņu prestiža un fundamentālo zinātņu krass sarukums. Līdzīgi procesi bija vērojami arī citās Austrumeiropas valstīs, īpaši Krievijā un bijušajās PSRS republikās, beidzoties plānveida ekonomikai. ${ }^{78}$

Zinātne Latvijā vairs nesaņēma politiskās elites un arī plašākas sabiedrības atbalstu. Kopš 90. gadu vidus zinātnei atvēlētā valsts budžeta daḷa ir krasi samazinājusies - šajā ziṇā Latvijas zinātne pastāvīgi ieņēma viszemākās pozīcijas Eiropas valstu (respektīvi, vēlāko ES dalībvalstu) vidū, jo valstij tika iezīmētas citas prioritātes (īpaši pakalpojumu un tranzītbiznesa jomā), bet privātais sektors zinātnei pievērsa maz vērības. Ja 1990. gadā triju Baltijas republiku skaitā Latvijas zinātne daudzos aspektos vēl bija līdere, tad pamazām tā sāka atpalikt no dinamiskās Igaunijas un apsviedīgās Lietuvas.

Tiesa, par spīti finansējuma trūkumam un zinātnieku skaita samazinājumam, Latvijas zinātnisko publikāciju iekḷāvums citējamo publikāciju datubāzēs nav krities, tas saglabājies stabils (taču Igaunijai un Lietuvai pieaugums ir bijis straujāks), ${ }^{79}$ un daudzu publikāciju zinātniskais līmenis starptautiski tiek vērtēts visai augstu.

77 Janis Kristapsons, Helle Martinson and Ina Dagyte, Baltic R\&D Systems in Transition. Experiences and Future Prospects (Riga: Zinatne, 2003).

78 Jānis Kristapsons, "Latvijas zinātne skaitl̦os," 490-492; Juris Balodis, ed., R\&D in Latvia: research and development in the Republic of Latvia, $3^{\text {rd }}$ rev. ed. (Riga: Latvian Technological Center, 2005); Jānis Kristapsons, Anda Adamsone-Fiskoviča and Anita Dravniece, ERAWATCH Country Reports 2010: Latvia, https:/www.researchgate.net/ publication/268035783_ERAWATCH_COUNTRY_REPORTS_2010_Latvia

79 Ibid. 


\section{Zinātnes sasniegumi atgūtās neatkarības gados un integrēšanās Eiropas zinātnes telpā}

Zinātnes attīstību Latvijā 21. gadsimtā būtiski ir ietekmējusi integrēšanās ES vienotajā zinātnes telpā vēl pirms Latvijas oficiālās iestāšanās Eiropas Savienībā 2004. gadā. Jau kopš 1998. gada Latvijas zinātnieki sāka sekmīgi līdzdarboties ES 5. ietvarprogrammā, vēlāk - arī turpmākajās. Iestāšanās Eiropas Savienībā un Eiropas struktūrfondu pieejamība iezīmēja pozitīvu pavērsienu zinātnes infrastruktūras, aparatūras un iekārtu atjaunināšanā, zinātnes un tehnologijas parku veidošanā. Iestājoties ES, Latvijai bija pamazām jāakceptē ES noteiktie kritēriji zinātnes finansēšanai. Cerības, kā vēlāk izrādījās - priekšlaicīgas, radīja 2005. gadā Latvijas Republikas Zinātniskās darbības likumā iekḷautā norma, ka Latvijai jānodrošina ikgadējs valsts finansējuma pieaugums zinātniskajai darbībai, ne mazāks par $0,15 \%$ no IKP gadā, līdz tas sasniedz 1 \% no IKP. ${ }^{80}$ Diemžēl šñ norma kopš 2008. gada ekonomiskās krīzes nav tikusi ievērota, finansējuma apjoms no nacionālā (valsts) budžeta zinātnei ir būtiski samazināts un 2016. gadā veido 38 miljonus eiro (0,15\% no IKP). Situāciju pašreiz kaut cik glābj ES struktūrfondu finansējums, kas zinātniekus sasniedz ar kavēšanos, bet kas tomēr cel̦ Latvijas zinātnes budžetu līdz 0,65\% IKP. ${ }^{81}$

2014. gadā Ziemel̦valstu Ministru padomes organizētā Latvijas zinātnes ekspertīze (nākamā pēc 1992. gadā veiktās) uzrādīja samērā neiepriecinošu ainu - no 150 izvērtētajām zinātniskajām institūcijām apmierinošu vērtējumu saņēma 67, kā l̦oti vājas tika atzîtas 23 institūcijas, bet par izcilām un l̦oti labām - tikai 15 institūcijas. No tām visaugstāko vērtējumu “5” ("izcili”) izpeln̄̄jās vien̄̄gi Latvijas Organiskās sintēzes institūts, atzīmes "l̦oti labi”" LU Cietvielu fizikas institūts, Latvijas Valsts koksnes ķīmijas institūts, Latvijas Biomedicīnas pētījumu un studiju centrs, Elektronikas un datorzinātņu institūts, Paula Stradiṇa Klīniskā universitātes slimnīca, Pārtikas drošības, dzīvnieku veselības un vides zinātniskais institūts "BIOR", Transporta un sakaru institūts, LU fizikas, optometrijas

80 Zinātniskās darbības likums, 33. pants, 2. daḷa. Sk.: Latvijas Zinātņu akadēmijas gadagrāmata 2006 (Rīga: Zinātne, 2006), 235.

81 Directorate-General for Research and Innovation at European Commission, Research and Innovation Performance in the EU. Innovation Union Progress at country level, 2014 (Luxembourg: Publications Office of the European Union, 2014), 169. 
un optisko zinību centrs, LU Datorikas fakultāte, LU Literatūras, folkloras un mākslas institūts (vienīgais no humanitāro zinātņu vides), Atomfizikas un spektroskopijas institūts, LU Ģeogrāfijas un zemes zinātṇu fakultāte, Ventspils Starptautiskais radioastronomijas centrs, Daugavpils Universitātes Gunta Liberta Inovatīvās mikroskopijas centrs. Ārzemju eksperti secināja, ka pētniecisko grupu un institūciju skaits Latvijā ir pārāk liels un sadrumstalots, cilvēku potenciāls tajās ir nepietiekams, taču kā galvenais neveiksmju cēlonis tiek atzîts "absolūti zemais pêtījumu finansējums visā [zinātnes] sistēmā. Katrai attīstītai valstij ir jāfinansē pētījumi pastāvīgi un ilgtermiṇā. Īslaicīgi finansējumi ir noderīgi pārveidojumu atbalstam, bet nevar būt pamats normālai funkcionēšanai (business as usual)". ${ }^{82}$

N̦emot vērā šos vērtējumus, kuri gan daudzos Latvijas pētniekos izraisīja neapmierinātību, 2014.-2016. gadā tika slēgti vai pārveidoti (apvienoti) daudzi pētniecības centri un notika zinātnisko institūciju pārskatīšana (konsolidēšana) saistībā ar valdības iecerēto augstākās izglītības un zinātnes reformu, kura gan norit pretrunīgi. ${ }^{83}$

Šìs pārmaiṇas saistītas arī ar krasu paaudžu nomaiṇu zinātnē, jo nākamajos gados pēc neatkarības atjaunošanas ir notikusi zinātnieku pakāpeniska novecošanās, kas īpaši skārusi arī LZA ievēlētos zinātniekus. Gadsimtu mijā jau bija izveidojies bīstams paaudžu pārrāvums.

Pēc iestāšanās ES kopš 2005. gada š̄ tendence dal̦ēji tika apturēta, zinātnē sāka ienākt jauni un visai spējīgi cilvēki. Tiesa, komunikācija ar zinātniekiem un augstskolām citās ES valstīs ir veicinājusi arī trešo emigrāciju. Pašreiz ārzemēs strādājošo Latvijas izcelsmes zinātnieku skaits pēc aptuveniem vērtējumiem ir vairāk nekā 1000 cilvēku, taču daudzi nevis emigrēe, bet migrēe (strādājot gan ārzemēs, gan Latvijā), iesaistoties doktora un īpaši postdoktorālajās studijās, daudzos sadarbības projektos ar ārvalstu zinātniekiem. Šai parādībai ir pozitīvā puse, jo, strādādami

82 Erik Arnold et. al., Latvia - Research Assessment Exercise: Summary report. Riga, 2014. Pieejams: http:/www.izm.gov.lv/images/zinatne/ZISI/zisi_03.pdf (skatīts 16.09.2016.) No J. Stradiņa personiskā arhīva.

83 Informatīvais ziņojums "Par pētniecības un inovācijas infrastruktūras un pētnieciskās darbības koncentrācijas teritoriālo kartējumu”. Pieejams: http://www.izm.gov. lv/lv/zinatne/zinatnisko-instituciju-teritorialais-kartejums. Pateicos Latvijas Zinātnes padomes priekšsēdētājam akadēmiķim Andrejam Siliņam par auglīgo diskusiju šo un citu Latvijas zinātnes aktuālo problēmu apskatā, kuras secinājumi daḷēji iekḷauti raksta nobeiguma sadal̦ā. 
ārzemēs, latviešu pētnieki dibina starptautiskus kontaktus, ieiet pasaules apritē, gūst pieredzi un panākumus. Minami piemēri, kad pēc 10-15 gadu prombūtnes dzimtenē atgriežas augstas klases pētnieki (kodolmagnētiskās rezonanses speciālists, Nobela prēmijas laureāta Kurta Vītriha skolnieks akadēmiķis Edvards Liepiņš un biologs Kaspars Tārs), kamēr cits kodolmagnētiskās rezonanses speciālists Ēriks Kupče turpina sekmīgi darboties Oksfordā. ${ }^{84}$ Sāk iezīmēties jaunu moderni domājošu zinātnieku paaudze ar starptautisku pieredzi, kas spēj sekmīgi iesaistīties Eiropas projektos, gūst ievērību savā nozarē. Vadošā vieta Latvijas zinātniekiem pašreiz gan ierādīta tikai vienā - datorzinātnieka Andra Ambaiņa vadītajā - projektā par kvantu skaitļotāju izveides teorētiskajiem pamatiem.

Iestāšanās ES un iesaiste Eiropas zinātniskajā telpā daudziem Latvijas zinātniekiem tātad l̦auj strādāt "vienotas lielvalsts" zinātnē un līdzdarboties arī "lielās zinātnes" veidošanā, taču nav skaidrs, cik veiksmīga būs Latvijas konkurētspēja Eiropas projektos nākotnē, vai ES ar struktūrfondiem spēs līdzfinansēt pētniecību Latvijā, kas pagaidām ir tās galvenais dzīvības avots. Vērojama valdības nenoteiktība pārdomātu zinātnes reformu veikšanā, nereti arī nevērība pret vietējiem zinātniekiem un to iespējām, viṇu ieteikumiem valsts ilgtspējīgas attīstības veicināšanai un Nacionālās attīstības plāna īstenošanā.

Pieticīgais finansējums un neizteiksmīgā zinātnes stratēgija Latvijas sabiedrībā un plašsaziņas līdzekl̦os palaikam uzjunda pārsteidzīgus spriedumus par zinātnes krīzi neatkarīgās Latvijas apstākḷos. Tā īsti nav Latvijā joprojām darbojas kvalitatīvi zinātnes centri, pētniecība rit sešās Latvijas universitātēs, daudzās akadēmijās un augstskolās, neatkarīgos pētniecības institūtos, arī reǵionos. Bez kvalitatīvas augstākās izglītības nav iedomājama kvalitatīva pētniecība, un pretēji, un augstākā izglītība Latvijā ir pietiekami kvalitatīva un atbilst starptautiskiem kritērijiem. 2014. gadā pētniecības jomā Latvijā strādāja 4138 zinātņu doktori, no tiem 3812 bija zinātnieku kategorijā (83,5 \% bija nodarbināti augstākās izglītības sektorā). ${ }^{85}$

Vairāki atjaunotās Latvijas zinātnieku veikumi guvuši starptautisku ievērību. Kā zīmīgākie piemēri minami magnētiskā lauka dinamo efekta

84 Jānis Stradiṇš, “Latviešu zinātnieki Latvijā un ārzemēs,” 59-60.

85 Pētniecības statistika. Informatīvais apskats (Rīga: Centrālā statistikas pārvalde, 2015), http://www.csb.gov.lv/sites/default/files/nr_36_petniecibas_statistika_15_00_ lv.pdf $\% 20$. 
eksperimentāls pierādījums (Agris Gailītis, Oḷgerts Lielausis, 1999), ${ }^{86}$ 360 miljonu gadu vecas pārejas formas no zivīm uz abiniekiem - Ventastega curonica atklāšana paleontoloǵijā (Ervīns Lukševics sadarbībā ar zviedru un krievu partneriem), ${ }^{87}$ oriǵinālas pieejas datorzinātnēs (Rūsiņš Mārtiņšs Freivalds, Andris Ambainis). ${ }^{88}$

Turpinot S. Hillera aizsāktās tradīcijas, Latvijas Organiskās sintēzes institūtā izstrādātais oriğinālais kardioprotektors un citoprotektors mildronāts (meldonijs) kḷuvis par nozīmīgāko Latvijas intelektuālo eksportpreci (Ivars Kalviņš), turklāt ir sintezēts vēl iedarbīgāks tā analogs, kam paredzama nākotne medicīnā; šo vielu darbības bioķīmiskie mehānismi pētīti saistībā ar karnitīna un $\gamma$-butirobetaīna darbību (Maija Dambrova u. c.). 2016. gadā sakarā ar meldonija iekl̦aušanu sportistiem aizliegto vielu sarakstā, kas radīja strīdus, interese par preparāta efektivitāti kardioloǵijāa strauji augusi starptautiskā līmen̄i. Ivars Kalviņš kā jaunu zāḷu vielu sintezētājs guvis starptautisku ievērību Eiropas mērogā. ${ }^{89}$

Sadarbībā ar ārzemju firmām Latvijas Organiskās sintēzes institūts izgudrojis un ieviesis arī vairākus principiāli jaunus medikamentus l̦aundabīgo audzēju, diabēta un Alcheimera slimības ārstēšanai (piemēram, pretvēža aǵents Belinostats 2014. gadā reǵistrēts ASV). Ar Ivara Kalviṇa gādību 2004. gadā oficiāli reǵistrēts un atļauts lietošanai Ainas Mucenieces, kādreizējās Augusta Kirhenšteina līdzstrādnieces, jau pasen izgudrotais ${ }^{90}$ dzīvo onkovīrusu preparāts Rigvir, kas izrādījies iedarbīgs pret melanomu. Arī š̄ preparāta darbības mehānisma pētījumi turpinās.

Materiālzinātnes, datorzinātnes un medicīnas zinātne ir tās nozares, kas mūsdienu Latvijā attīstās visai sekmīgi. ${ }^{91}$ Andra Šternberga vadītais

86 Latvijas Zinātņu akadēmijas gadagrāmata, 2000 (Rīga: Zinātne, 2000), 114, 123.

87 Latvijas Zinātņu akadēmijas gadagrāmata, 2012 (Rīga: Zinātne, 2012), 17-18.

88 Andris Ambainis, "Rūsin̦š Mārtin̦š Freivalds (10.11.1942.-04.01.2016.). In memoriam," Zinātnes Vēstnesis, 25. janvāris, 2016, 4; Egīls Zirnis un Vents Zvaigzne, “Latvietis pasaules melnajā kastē," SestDiena, 1./7. februāris, 2013, 18-22.

89 Ilze Barone, sast., Latvijas Zinātņu akadēmijas akadēmiķis profesors Ivars Kalviņš: biobibliogrāfija (Rīga: Latvijas Akadēmiskā bibliotēka, 2007); Ivars Kalviņš, "Vīruss kā dresēts medību suns". Pierakst. Z. Eniṇa. 36,6 C: Veselīgāk. Saskan̄̄gāk. Gudrāk, 6 (2016): 8-13.

90 Aina Mutsenietse, Onkotropizm virusov i problema viroterapii zlokachestvennykh opukholei (Riga: Zinatne, 1972).

91 Ineta Kurzemniece un Gatis Bažbauers, Zinātniskās darbības rezultātu izvērtējums specializāciju noteikšanai pētniecībā (Rīga: LU Akadēmiskais apgāds, 2014). 
LU Cietvielu fizikas institūts nodarbojas ar jaunu funkcionālo materiālu un nanotehnologiju pētniecību (segnetoelektriskie materiāli, funkcionālie materiāli elektronikai, fotonikai un enerğētikai, radiācijas izturības materiālu izstrāde Starptautiskā kodoltermiskās sintēzes eksperimentālā reaktora ITER vajadzībām u. c.). Šis institūts guvis Eiropas komisijas ekselences centra statusu materiālzinātnēs. ${ }^{92}$ LU fiziķi izpelnījušies ievērību ar saviem pētījumiem atomfizikas un lāzerspektroskopijas jomā, Mārcis Auziņš un Ruvims Ferbers publicējuši grāmatas prestižās starptautiskās izdevniecībās.

Medicīnā, īpaši invazīvajā kardioloǵijā un kardioķirurǵijā, gūti ievērojami panākumi moderno metožu ieviešanā un pilnveidošanā, šî joma Latvijā ir labi attīstīta. Latvija izceļas arī ar vairāku inovatīvu pārtikas produktu ražošanu eksportam un pašmāju vajadzībām, ar agrobioloǵijas, mežizstrādes un koksnes izmantošanas problēmu praktiskiem risinājumiem. Daugavpilī enerǵiskā Daugavpils Universitātes rektora Arvīda Barševska vadībā notiek starptautiski atzīti vaboḷu (pat Filipīnu arhipelāgā mītošās Doliops ǵints vaboḷu) pētījumi, tiek izdots starptautisks koleopteroloǵijas žurnāls. ${ }^{93}$

Biomedicīnas pētījumu un studiju centrā izveidota Latvijas iedzīvotāju gēnu datu banka, ir labas iestrādes vēža biomarķieru meklējumos un ir atzītas novitātes gēnu inženierijas, biofarmācijas, farmakoloğijas un organiskās ķīmijas jomā. Šo pozitīvo piemēru virkni varētu vēl turpināt.

Uz kādreiz īpaši slepenā PSRS kosmiskās izlūkošanas objekta Zvjozdočka bāzes 1996.-1999. gadā ir izveidots lielākais Latvijas pētniecības infrastruktūras objekts - Ventspils Starptautiskais radioastronomijas centrs (VSRC) Ventspils tuvumā, kas pēc rekonstrukcijas 2015. gadā tika iesaistīts garās bāzes interferometrijas tīklā kopā ar teleskopiem Polijā, Zviedrijā, Vācijā, Krievijā, Somijā un Nīderlandē. ${ }^{94}$ 2015. gadā Latvija kḷuva par Eiropas Kosmosa aǵentūras sadarbības valsti, kas ḷauj tai piedalīties šîs aǵentūras rīkotajos konkursos par jaunu kosmosa tehnoloǵiju izstrādi Eiropas Savienībai.

92 Andris Šternbergs, iev., Latvijas Universitātes Cietvielu fizikas institūts: pētniecības aktualitātes (Rīga: Latvijas Universitātes Cietvielu fizikas institūts, 2013).

93 Latvijas Zinātņu akadēmijas gadagrāmata, 2016 (Rīga: Zinātne, 2016), 66-70.

94 Jānis Stradin̦š, Latvijas Zinātņu akadēmija: izcelsme, vēsture, pārvērtības, 530-532; Arturs Balklavs, "Dramatiska cīṇa par Ventspils antenām un VSRC," Zvaigžnotā Debess (pavasaris 1995): 60-63; Dainis Draviņš, "Par Ventspils radioantenām un to nākotnes perspektīvām,” Zvaigžņotā Debess (vasara 1995): 52-57. 
Kopš 2002. gada Latvijas Zinātņu akadēmija katra gada nogalē definē gada 10-12 nozīmīgākos sasniegumus zinātnē, lai pievērstu sabiedrības uzmanību zinātnes novitātēm Latvijā. ${ }^{95}$

Latvijas zinātnē varētu iezīmēties arī jauns modelis - zinātnieki izcel̦otu uz ES valstīm un ASV, tomēr saglabājot saistību ar dzimteni, un (kas būtu labāk!) pētniecības darbs Latvijā notiktu kopēju starptautisku projektu ietvaros, kas ir iespējams moderno tehnolog̣iju laikmetā. Taču mērkstiecīgāk būtu veidot mazas valsts zinātni lielajā Eiropas un pasaules zinātnē ar nozīmīgiem pētniecības centriem (vismaz atsevišksās nozarēs) Baltijā un ar garantētu valsts finansējumu kaut vai nacionālajās un reǵionālajās zinātnēs. Latvijā jāsaglabā vismaz vairāki augsta līmeņa pētnieciski institūti, lai tā nekḷūtu par Eiropas nomali, kur pētniecībā nekas būtisks vairs netiek veikts. ${ }^{96}$

Pēc finanšu krīzes seku dal̦ējas pārvarēšanas kopš 2012. gada ar Eiropas Savienības fondu palīdzību un valsts līdzfinansējumu pēdējos gados iezīmējas pozitīvi procesi - zinātniskā infrastruktūra tiek modernizēta un atjaunota. Var minēt LU jauno akadēmisko Dabaszinātņu centru Torņakalnā (2015), LU Humanitāro zinātņu centru (2014), RTU, RSU, Latvijas Lauksaimniecības universitātes, Daugavpils Universitātes, Rēzeknes Tehnoloğiju akadēmijas u. c. augstskolu jaunceltnes, jauno Latvijas Organiskās sintēzes institūta Latvijas Biomedicīnas pētījumu un studiju centra pētījumu korpusu (2016) un par Eiropas līdzekļiem iegādātos modernos aparātus, piemēram, $900 \mathrm{MHz}$ kodolmagnētiskās rezonanses spektrometru.

Ar Eiropas Sociālā fonda palīdzību sagatavoti jaunie zinātņu doktori (pēdējā laikā ik gadus Latvijā tiek aizstāvēti 250-300 promocijas darbi, kuriem bieži seko postdoktorālās studijas ārzemēs) - līdz 2015. gadam šis process ritējis līdztekus zinātniskās infrastruktūras attīstībai. Programma "Horizon - 2020" l̦auj cerēt uz pozitīvo tendenču turpināšanos, lai gan šajā ceḷā iezīmējušās grūtības un neskaidrības.

Diemžēl vairāku apstākḷu dẹḷ Latvija patlaban atpaliek no attīstītajām ES valstīm inovatīvu izgudrojumu komercializācijas ziņā. Par spīti niecīgajam valsts atbalstam un vājām privātām iniciatīvām, Latvijā joprojām darbojas inovatīvi zinātnieki, izgudrotāji, ir izstrādāts inovatīvo zinātnes

95 Latvijas Zinātṇu akadēmijas gadagrāmatas, 2004-2018. http://www.lza.lv/index. php?option=com_content\&task=blogcategory\&id=18\&ltemid=57

96 Jānis Stradin̦š, "Vai Latvijas Republikai vajadzīgi zinātnieki?" no Zinātnes un kultūras mijiedarbība Latvijā un pasaulē: Jāņa Stradiņa gada grāmata, 18-28. 
un tehnolog̣iju stratēgiju projekts Latvijas konkurētspējas paaugstināšanai, inovatīvo un perspektīvo nozaru identificēšanai un stimulēšanai. Pēdējā laikā iezīmējas vēlme uzsvērt praktiskos, utilitāros aspektus zinātnē, augstskolās atbalstīt dabaszinātņu un inženierzinātņu studijas, mēǵināt audzināt uz uzṇēmējdarbību orientētus speciālistus, attīstīt tēmas, kas būtu saistītas ar produktu komercializēšanu lielajos Latvijas uzņēmumos, ar inovatīvu mazo un vidējo uzņēmumu veidošanu.

ES fondi prioritāri tiek virzīti Latvijas industrijas potenciālai specializācijai viedās specializācijas jomās: 1) zināšanu ietilpīga bioekonomika (inovatīva meža audzēšana, koksnes izmantošana, augu un dzīvnieku audzēšana un pārstrāde, pārtikas drošība); 2) biomedicīna, medicīnas tehnoloǵijas, biofarmācija un biotehnoloǵijas; 3) viedie materiāli, tehnoloǵijas un inženiersistēmas; 4) viedā enerǵētika; 5) informācijas un komunikāciju tehnoloǵijas. ${ }^{97}$

Drīzumā būs redzams, vai līdztekus iecerētajam "ekonomikas uzrāvienam” Latvijā izdosies īstenot arī "inovatīvās zinātnes uzrāvienu”, vai vietējā vidē tam atradīsies nepieciešamie resursi, intelektuālā kapacitāte un uzņēmēju iniciatīva.

Vienlaikus arvien spēcīgāk izskan humanitārās nozares pārstāvošo pētnieku viedoklis. Viņi akcentē zināšanu un vērtību nozīmību Latvijā ne tikai utilitārā, bet arī ētiskā, morālā aspektā un uzsver nacionālās identitātes svarīgumu un Latvijas kultūras eiropeisko raksturu. Šajā sakarā jāmin filozofes Maijas Kūles grāmata "Jābūtības vārdi. Etīdes par zināšanām un vērtībām mūsdienu Latvijā” (2016), viņas kritiskas ievirzes grāmata "Eirodzīve: formas, principi, izjūtas" (2006) un daudzi Latvijas filozofu un sociologu pētījumi. Rezonansi izpelnījušās arī politologa un Latvijas neatkarības atgūšanas aktīva dalībnieka un norišu vērtētāja Tālava Jundža grāmatas un dokumentālo avotu izdevumi par nevardarbīgo pretošanos Latvijā (1987-1991). ${ }^{98}$ Vispārzinātniska nozīme, ne tikai Latvijā, ir fiziķa Edgara Imanta Siliņa lieliskajai un Latvijā populārajai grāmatai par zinātnes filozofiju "Lielo patiesību meklējumi” (1. izd. 1999, 2. izd. 2006). ${ }^{99}$

97 “Ministru kabineta 2013. gada 28. decembra rīkojums Nr. 685. Par Zinātnes, tehnolog̣iju attīstības un inovāciju pamatnostādnēm 2014.-2020. gadam,” http://likumi.lv/ doc.php?id=263464.

98 Talavs Jundzis, ed., Regaining Independence: Non-Violent Resistence in Latvia, 1945-1991 (Riga: Latvian Academy of Sciences, 2009).

99 Edgars Imants Siliņš, Lielo patiesību meklējumi (Rīga: Jumava, 1995), 2. izd. (Rīga: Jumava, 2006). 
Visspilgtāk nacionālās identitātes un vēsturiskā mantojuma problēmas atjaunotās neatkarības gados izvērtēja programmas "Letonika" ietvaros (un arī ārpus tās) veiktie starpdisciplinārie pētījumi, kas apvienojuši dažādu nozaru pētniekus no daudzām Latvijas augstskolām un pētniecības institūcijām. ${ }^{100}$ Šìs programmas pirmās vadlīnijas tika iezīmētas 1995. gadā, taču valsts finansētu pētījumu cikli sākās ar 2005. gadu programmas "Letonika" un programmas "Nacionālā identitāte: valoda, Latvijas vēsture, kultūra un cilvēkdrošība" ietvaros. Kopš 2005. gada tiek regulāri rīkoti Letonikas kongresi (līdz 2015. gadam tādi ir bijuši seši), izdoti attiecīgi rakstu krājumi un četru sējumu izdevums latviešu valodā "Latvieši un Latvija" (2013), kas jau guvis sabiedrības atzinību un ir apbalvots ar Latvijas Republikas Ministru kabineta balvu. ${ }^{101}$

Būtisks ir apstāklis, ka atjaunotajā Latvijā stabilizējusies letonistika (letonika) kā humanitāro un sociālo zinātñu starpnozaru kopums, kas pētī latviešus un Latviju. Pētījumi par latviešu valodu aptver valodas un valodniecības vēsturi, dialektoloǵiju, onomastiku, gramatikas jautājumus, sociolingvistiskos aspektus (Marta Rudzīte, Aina Blinkena, Ilga Jansone, Ina Druviete, Anna Stafecka u. c.). Latvijas vēsturē akcents likts uz Latvijas 20. gadsimta l̦oti sarežǵīto politisko vēsturi (Inesis Feldmanis, Aivars Stranga, Jānis Bērziņš, Valdis Bērziņš, Indulis Ronis, Daina Bleiere, Vita Zelče u. c.). Starptautiski atzīti darbi veikti arheoloǵijā (Ēvalds Mugurēvičs, Jānis Graudonis, Andris Caune, Ilze Loze, Andrejs Vasks, Juris Urtāns, Ieva Ose, Guntis Zemītis u. c.). İpaši atzīmējamas daudzās seno hroniku edīcijas (E. Mugurēvičs) un jauns skatījums uz Rīgas pilsētas izcelsmi un agrīno vēsturi (A. Caune). ${ }^{102}$

Ļoti nozīmīgi ir pētījumi folkloristikā (Kārlis Arājs, Vaira V̄̄ķeFreiberga un Imants Freibergs, Beatrise Reidzāne, Janīna Kursīte-Pakule,

100 Jānis Stradiṇš un Saulvedis Cimermanis, "Par letonikas jēdzienu un saturu," Latvijas Zinātņu Akadēmijas Vēstis. A dal̦a, 5/6 (1995): 1-7; Ilga Jansone, "Valsts pētījumu programma "Letonika: pētījumi par vēsturi, valodu un kultūru"," no Letonikas pirmais kongress: plenārsēěu materiāli. Rīga, 2005. 24.-25. oktobris (Rīga: Latvijas Zinātṇu akadēmija, 2006); Jānis Stradiṇš, "Letonikas sākotne un nākotne," Latvijas Vēsture: jaunie un jaunākie laiki, 1 (2008): 57-66.

101 Jānis Stradiņš, galv. red., Latvieši un Latvija: akadēmiskie raksti, 4 sēj. (Rīga: Latvijas Zinātṇu akadēmija, 2013).

102 Latvijas vēsturnieku darbības izvērtējumu pēdējos gados sk. arī krājumā: Inesis Feldmanis un Jānis Taurēns, red., Latvijas vēsture krustcelēs un jaunu pieeju meklējumos (Latvijas vēsturnieku I kongresa materiāli) (Rīga: LU Akadēmiskais apgāds, 2014). 
Dace Bula u. c.), jo šajā jomā latviešu nācijai ir unikāls un bagāts mantojums. Krišjāṇa Barona Dainu skapis un Latviešu folkloras krātuve, kas kopš 2014. gada atrodas Latvijas Nacionālās bibliotēkas jaunceltnē, kḷuvuši par nācijas relikviju un guvuši gandrīz vai sakrālu vērtību.

Saules traktējums latviešu mutvārdu daiļradē - folklorā kḷuvis par ievērojamās latviešu zinātnieces folkloristes, Latvijas Republikas Valsts prezidentes (1999-2007) Vairas Vīkses-Freibergas mūža misiju. Kopā ar dzīvesbiedru Imantu Freibergu viņi savulaik ne tikai pirmie izveidojuši latviešu tautas dziesmu datu bāzi (jau Monreālā, Kanādā 1982, ap 71000 dainu), bet īpaši arī to tautas dziesmu datu bāzi, kurās pieminēta saule. 2016. gadā ar piecu sējumu monogrāfiju kopu noslēdzies V. VīķesFreibergas analītiskais pētījums "Trejādas saules" par saules dainām, aplūkojot tajā saules dažādus traktējumus dainās: kosmoloǵiskā, hronoloǵiskā, meteoroloǵiskā, fiziskā un mitoloǵiskā aspektā, kas ir jauna pieeja tradicionālo folkloras vērtību padzilināatai izpratnei. ${ }^{103}$

Sabiedrībā novērtēti arī pētījumi par latviešu literatūras, teātra, kino vēsturi (Viktors Hausmanis, Jānis Kalniņš, Vera Vāvere, Benedikts Kalnačs, Māra Grudule, Lilija Dzene, Guna Zeltiņa, Silvija Radzobe u. c.). Mākslas un arhitektūras vēsturē izcel̦ami Jāņa Krastiņa, Jāṇa Zilgalvja, Imanta Lancmaņa, Ojāra Spārīša, Elitas Grosmanes, Eduarda Kḷaviņa u. c. veiktie pētījumi, kas aptver plašu laikmetu diapazonu, iekl̦aujot tajā arī cittautu, pirmām kārtām baltvācu, kultūras mantojumu. Pētnieki nav aprobežojušies ar latviešu devumu vien, bet centušies uzsvērt arī Latvijas un īpaši tās pilsētu un muižu multikulturālo raksturu, kas mūsdienās devis vielu arī politizētām diskusijām. Atzīmējami ir Saulveža Cimermaņa un Heinriha Stroda pētījumi etnogrāfijā un agrārajā vēsturē, Pētera Zvidriņa, Ilmāra Meža u. c. pētījumi un spriedumi par latviešiem visai sāpīgu tēmu - demogrāfiju. Minētie pētījumi krājumā plašāk aplūkoti citu autoru rakstos.

Humanitārajās zinātnēs, bez šaubām, latviešiem ir veiksmes stāsti. Daudzi zinātnieki un viņu darbi guvuši pietiekamu atpazīstamību vietējā sabiedrībā, taču šie pētījumi ne vienmēr ir pietiekami koordinēti ar kaimiñvalstu zinātniekiem (pozitīvs piemērs ir līdzdalība Eiropas valodu atlantā), ne visi ir pieejami svešvalodās. Arī interese par Latvijas problēmām

103 Ausma Cimdiña, red., Scientiae et patriae: veltījums akadēmiksei profesorei Vairai Vīkei-Freibergai 75. dzimšanas dienā = Scientiae et Patriae: a Festschrift in honour of Vaira Vīke-Freiberga on his 75th birthday (Rīga, LU Akadēmiskais apgāds, 2012); Vaira Vīkse-Freiberga, Trejādas saules, 5 sēj. (Rīga: Karogs; Pētergailis, 1997-2016). 
pasaulē diemžēl vēl nav pietiekama (patīkami izṇēmumi šajā ziṇā bija krievu valodnieki Vladimirs Toporovs, Oḷegs Trubačovs, itāḷu valodnieks Pjetro Umberto Dini, angḷu vēsturnieks Džons Haidens u. c.). Latvijas vēstures problēmas ārzemēs joprojām nereti aplūko Baltijas vācu vai vācu vēsturnieku senāko sacerējumu skatījumā, nepamanot latviešu vēsturnieku jaunākos pētījumus. Tiesa, stāvoklis pakāpeniski sāk uzlaboties, taču tematikas padziļināšana, letonikas "modernizācija" un secinājumu paplašināšana Eiropas kontekstā būtu nākamo gadu virsuzdevums. Latvija un latvieši jāparāda pasaulei, taču letonistika vispirms nepieciešama tieši latviešiem kā viens no pašapziņas, intelektuāla kultūras patriotisma un nacionālās paškritikas avotiem.

Jāpiebilst, ka latviešu zinātnieki pētījuši ne tikai letonistiku vien, bet arī cittautu problēmas. Šajā aspektā atzīmējami, piemēram, pētījumi par indoloǵiju (Viktors Ivbulis), ${ }^{104}$ par Viljama Šekspīra recepciju ${ }^{105}$ Baltijā (Guna Zeltiņa, 2015), ${ }^{106}$ tāpat par Ėgiptes piramīdu topologiju (Jānis Klētnieks).

Padomju režīma apstākl̦os tikai daži Latvijas zinātnieki tika ievēlēti par locekḷiem PSRS Zinātņu akadēmijā vai PSRS Medicīnas Zinātņu akadēmijā (Jānis Peive, Aleksandrs Mālmeisters, Bruno Puriņš, Aleksandrs Šmits, Pauls Stradiņš, Viktors Kalnbērzs u. c.), Solomons Hillers kḷuva par Vācu Dabaspētnieku akadēmijas Leopoldina locekli. Neatkarīgajā Latvijā starptautisku atzinību guvis lielāks skaits Latvijas zinātnieku. Academia Europae locekḷu skaitā minami Mārcis Auziņš, Andrejs Cēbers, Elmārs Grēns, Aija Linē, Rūsiņš Mārtiņš Freivalds un Vitauts Tamužs. Vācijas Nacionālās Zinātñu akadēmijas Leopoldina īstenais loceklis ir Jānis Stradiņš, Krievijas ZA korespondētājloceklis - Elmārs Grēns. Vaira VīķeFreiberga ir Kanādas Karaliskās biedrības īstenā locekle un savulaik bijusi tās Humanitāro un sociālo zinātņu akadēmijas prezidente. Vairāki LZA locekḷi ir arī Igaunijas, Lietuvas, Gruzijas nacionālo ZA ārzemju locekḷi, Zviedrijas Karaliskās Inženierzinātņu akadēmijas un Zviedrijas Karaliskās Lauksaimniecības un meža zinātṇu akadēmijas ārzemju locekḷi. ${ }^{107}$ Daudz Latvijas zinātnieku ir austrieša Feliksa Ungera dibinātajā Academia

${ }^{104}$ Latvijas Zinātņu akadēmijas gadagrāmata, 2015 (Rīga: Zinātne, 2015), 71-76.

105 Recepcija - kādu (cita laikmeta, citas zemes, tautas u. tml.) sociālu un kultūras elementu aizgūšana (sk. http://www.tezaurs.lv/\#/sv/recepcija).

106 Gundega Zeltiṇa, Šekspīrs. Ar Baltijas akcentu (Rīga: LU Literatūras, folkloras un mākslas institūts, 2015).

107 Latvijas Zinātņu akadēmijas gadagrāmata, 2016 (Rīga: Zinātne, 2016), 194. 
Scientiarum et Artium Europae Zalcburgā, kura aktīivi sadarbojas ar Latviju, regulāri rīko šeit savas izbraukuma sēdes un piešķir Latvijas zinātniekiem un māksliniekiem īpašas Feliksa balvas (laureātu skaitā bijuši Vaira Vīkse-Freiberga, Maija Kūle, Ilmārs Blumbergs, Imants Lancmanis u. c.). ${ }^{108}$ Vairāki Latvijas pārstāvji kopš 1994. gada saņēmuši Baltijas asamblejas balvas zinātnē (laureātu skaitā Andris Caune, Jānis Krastiṇš, Janīna Kursīte, Ēvalds Mugurēvičs, Jānis Stradiņš, Renāte Blumberga, Maija Dambrova u. c.). 1999. gadā pēc Latvijas ierosinājuma tika atjaunota Baltijas intelektuālās sadarbības konferenču tradīcija, kuru aizsāka 1935. gadā (mūsdienās tādas regulāri rīko Baltijas valstu un Somijas zinātņu akadēmijas). 109

Liela vērība tikusi veltīta arī vietējo zinātnes tradīciju saglabāšanai un izkopšanai - ievērojamāko zinātnieku vārdā nosauktas LZA un universitāšu pieškiramās vārdbalvas un medaļas, daudziem no viņiem uzstādītas piemiņas zīmes, kopš 1958. gada Rīgā, Viḷṇā, Tartu vai Tallinā regulāri notiek Baltijas zinātņu vēstures konferences (27. Baltijas zinātņu vēstures konference notika 2015. gada ruden̄̄ Rīgā un Jelgavā saistībā ar Academia - 200 gadu, un tā bija apvienota ar Eiropas Zinātṇu un mākslu akadēmijas izbraukuma sēdi). ${ }^{110}$

Lai gan Eiropas Komisijas 2014. gada rakstu krājumā "Research and Inovation Performance in the EU", kurā apkopoti salīdzinoši dati par finansējumu inovācijām dažādās valstīs (tostarp trijās Baltijas valstīs), izteikta neticība solījumiem, ka situācija zinātnes un inovāciju jomā Latvijā varētu būtiski uzlaboties līdz 2020. gadam, kā tas iecerēts programmā

108 Jānis Stradiṇš, "Eiropas Zinātṇu un mākslu akadēmija un tās saistība ar Latvijas vēsturi," Zinātņu vēsture un muzejniecība = History of Sciences and Museology, Latvijas Universitātes Raksti (Rīga: LU Akadēmiskais apgāds, 2011), 763 : 225-231.

109 Jānis Stradiñš, "Beginnings of the Intellectual Entente of the Baltic States (19201935-1940)," Scientific Proceedings of Riga Technical University. Ser. 8. History of Science and Higher Education 18 (2011): 11-18 (ar Baltijas intelektuālās sadarbības konferenču un Baltijas asamblejas laureātu pilnu sarakstu līdz 2010. gadam).

110 Kopš 1958. gada tiek regulāri rīkotas Baltijas zinātṇu vēstures konferences (2015. gadā Rīgā un Jelgavā notika jau 27. šāda veida konference). Sk.: Jānis Stradiņš, "Latvijas Zinātṇu vēstures asociācijas pirmsākumi un organizētas zinātṇu vēstures pētniecības 50 gadi Baltijā," Zinātņu vēsture un muzejniecība = History of Sciences and Museology, Latvijas Universitātes Raksti (Rīga: LU Akadēmiskais apgāds, 2008), 738: 197-215; Jānis Stradiňš, “27. Baltijas zinātṇu vēstures konference,” Latvijas Zinātņu Akadēmijas Vēstis. A dala, 5/6 (2015): 108-111. 
"Latvija 2020", 111 taču vairākos $R \& D$ sektoros vērojamās pozitīvās tendences vieš cerības uz vietējās zinātnes augšupeju.

Latviešiem raksturīga spēcīga izglītošanās un pētniecības tieksme, viņi joprojām ir spējīgi ǵenerēt sasniegumus dažnedažādās zinātnes jomās, strādādami gan dzimtenē, gan ārpus tās, arī starptautiskos projektos.

Līdzdalība starptautiskajā zinātnē arvien tiek uzskatīta par vienu no modernās identitātes izpausmēm, tomēr ES federālisms nedrīkst iznīdēt atsevišksu valstu nacionālās savdabības - tas ir viens no zinātnes (un kultūras) pastāvēšanas pamatnoteikumiem mazā valstī. Finansiālu nodrošinājumu "nacionālajām zinātnēm" daudzinātie Eiropas Savienības fondi neparedz, taču Latvijai arī turpmāk ES ietvaros jāattīstās kā valstij ar izteiktu nacionālo identitāti līdz ar tradicionālo multikulturālismu (īpaši lielajās pilsētās), tādēḷ mūsu sabiedrībā tiek mēǵināts iesakṇot atziṇu, ka letonistikas un humanitāro, tostarp sociālo, zinātņu kopums Latvijas valstij jāatbalsta ar saviem līdzekḷiem, lai pētītu un pamatotu nacionālās un eiropeiskās identitātes faktorus Latvijā. Zinātnes uzdevums vispār ir kritiskas, brīvdomīgas gaisotnes uzturēšana sabiedrībā. Saprotams, īpašas rūpes jāveltī lielās zinātnes un inovatīvo tehnoloǵiju attīstīšanai mazā valstīe kas būtu vietējo zinātnieku sabiedrības pamatuzdevums, risinot to savu iespēju robežās globalizētajā pasaulē.

\section{Science in Latvia: Characteristics of Its Development (1775-2016)}

\section{Summary}

If the development of science on the territory of Latvia is considered as a continuous process from the period of the Enlightenment onwards, then the following stand out as the main research institutions of their times: Academia Petrina at Jelgava, numerous Baltic German professional associations of the $19^{\text {th }}$ century, Riga Polytechnic (Riga Polytechnic) Institute, University of Latvia, Latvian Academy of Sciences with its diverse

111 Directorate-General for Research and Innovation at European Commission, Research and Innovation Performance in the EU. Innovation Union Progress at country level, 2014, 169-178. 
institutes, and the science network of the independent Latvia with its many institutions, in which the dominant role is played by major universities and several powerful independent institutes. Over and above the development of science in Latvia, Latvian scientists have successfully pursued research careers outside the country from the end of the $19^{\text {th }}$ century onwards. This mobility and the foreign component of Latvian science have come about as a result of many political and social influences and the international nature of science taken together. Significant scientific results conforming to international standards have been achieved in Riga throughout all its development phases; these have occurred in various branches of science (in particular in chemistry and material science, medicine and pharmaceuticals, informatics, etc.), and local schools of science have developed with stable scientific traditions. Science in Latvia developed in the context of the world science and local scientists (including ones of Baltic German origin) have over a long period of time ensured comprehensive study of the Latvian ethnos, its culture, and local history.

After the recovery of the independence of Latvia in 1991, science in the country has developed within the single research area of the European Union, paying particular attention to investigation of local problems, in particular studying Latvian identity and multi-cultural issues (in humanities). At present, the chief obstacle to substantial development is a chronic insufficiency of funding from the national budget, a system of research and higher education which is partially in disarray, and the emigration of many young scientists going abroad to countries which are scientifically more attractive. During the period of independence, scholars from Latvia have produced success stories in various sectors, but lack of financing has prevented realising grand projects. In spite of very slight support by the state and private entrepreneurs, innovative scientists and inventors are active in Latvia, but, regrettably, Latvia still lags behind the developed EU member states in the commercialisation of innovative inventions. A strategy is being drafted to help remedy this situation. Currently science in Latvia largely relies on financial support from various European Union programmes, and these funds are being used to renew infrastructure, procure new apparatus, and establish new buildings for universities and institutes. A new model has emerged for modern relations, i.e. emigration by young scientists to other EU member states, the USA and Great Britain, at the same time retaining their links with their homeland, i.e., to carry out joint projects. The strategic 
goals for science in Latvia ought to be creation of science in a small state within the science pursued in the wider world and in Europe, while retaining and developing the most important research centres at home at the highest level of excellence. We must clearly identify those sectors and directions in which we can realistically be competitive in the European Union and world-wide, and resources need to be allocated for these. Science in Latvia has to be developed at two different levels, i.e. meeting the local needs of Latvia (in terms of technology and in the study and promotion of national identity), as well as a fundamental direction, which is capable of representing Latvia in the EU and in the wider world, in cooperation with researchers in other countries.

\section{Jānis Stradiṇš}

Dr. habil. chem., Dr. hist. h. c.

Latvijas Zinātņu akadēmijas îstenais loceklis /

Latvian Academy of Sciences, full member 